\title{
Evaluation of Vitrification Factors from DWPF's Macro-Batch 1
}

by

T. B. Edwards

Westinghouse Savannah River Company

Savannah River Site

Aiken, South Carolina 29808

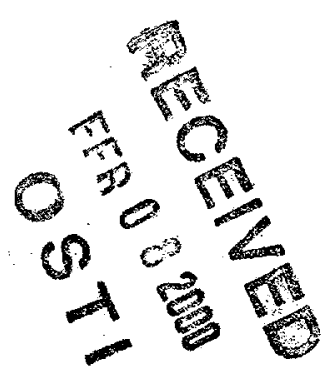

This paper was prepared in connection with work done under the above contract number with the U.S.

Department of Energy. By acceptance of this paper, the publisher and/or recipient acknowledges the U.S. Government's right to retain a nonexclusive, royalty-free license in and to any copyright covering this paper, along with the right to reproduce and to authorize others to reproduce all or part of the copyrighted paper. 
Keywords: MFT, SME,

Statistics

Retention Time: Permanent

\section{Evaluation of Vitrification Factors from DWPF's Macro-Batch 1 (U)}

T. B. Edwards

Westinghouse Savannah River Company

Savannah River Technology Center Aiken, SC 29808

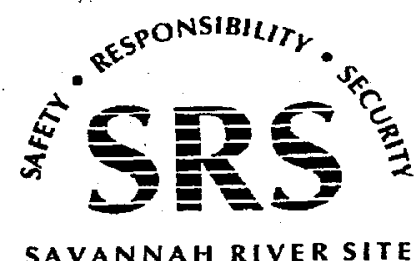

PREPARED FOR THE U.S. DEPARTMENT OF ENERGY UNDER CONTRACT NO. DE-AC09-96SR18500 


\section{DISCLAIMER}

This report was prepared as an account of work sponsored by an agency of the United States Government. Neither the United States Government nor any agency thereof, nor any of their employees, makes any warranty, express or implied, or assumes any legal liability or responsibility for the accuracy, completeness, or usefulness of any information, apparatus, product or process disclosed, or represents that its use would not infringe privately owned rights. Reference herein to any specific commercial product, process or service by trade name, trademark, manufacturer, or otherwise does not necessarily constitute or imply its endorsement, recommendation, or favoring by the United States Government or any agency thereof. The views and opinions of authors expressed herein do not necessarily state or reflect those of the United States Government or any agency thereof.

This report has been reproduced directly from the best available copy.

Available for sale to the public, in paper, from: U.S. Department of Commerce, National Technical Information Service, 5285 Port Royal Road, Springfield, VA 22161, phone: (800) 553-6847

fax: (703) 605-6900

email: orders@ntis.fedworld.gov

online ordering: http://www.ntis.gov/ordering.htm

Available electronically at http://www.doe.gov/bridge

Available for a processing fee to U.S. Department of Energy and its contractors, in paper, from: U.S. Department of Energy, Office of Scientific and Technical Information, P.O. Box 62, Oak Ridge, TN 37831-0062, phone: (865) 576-8401

fax: (865) 576-5728

email: reports@adonis.osti.gov 


\section{DISCLAIMER}

Portions of this document may be illegible in electronic image products. Images are produced from the best available original document. 


\section{Evaluation of Vitrification Factors from DWPF's Macro-Batch 1 (U)}

October 15, 1999

Document Approvals

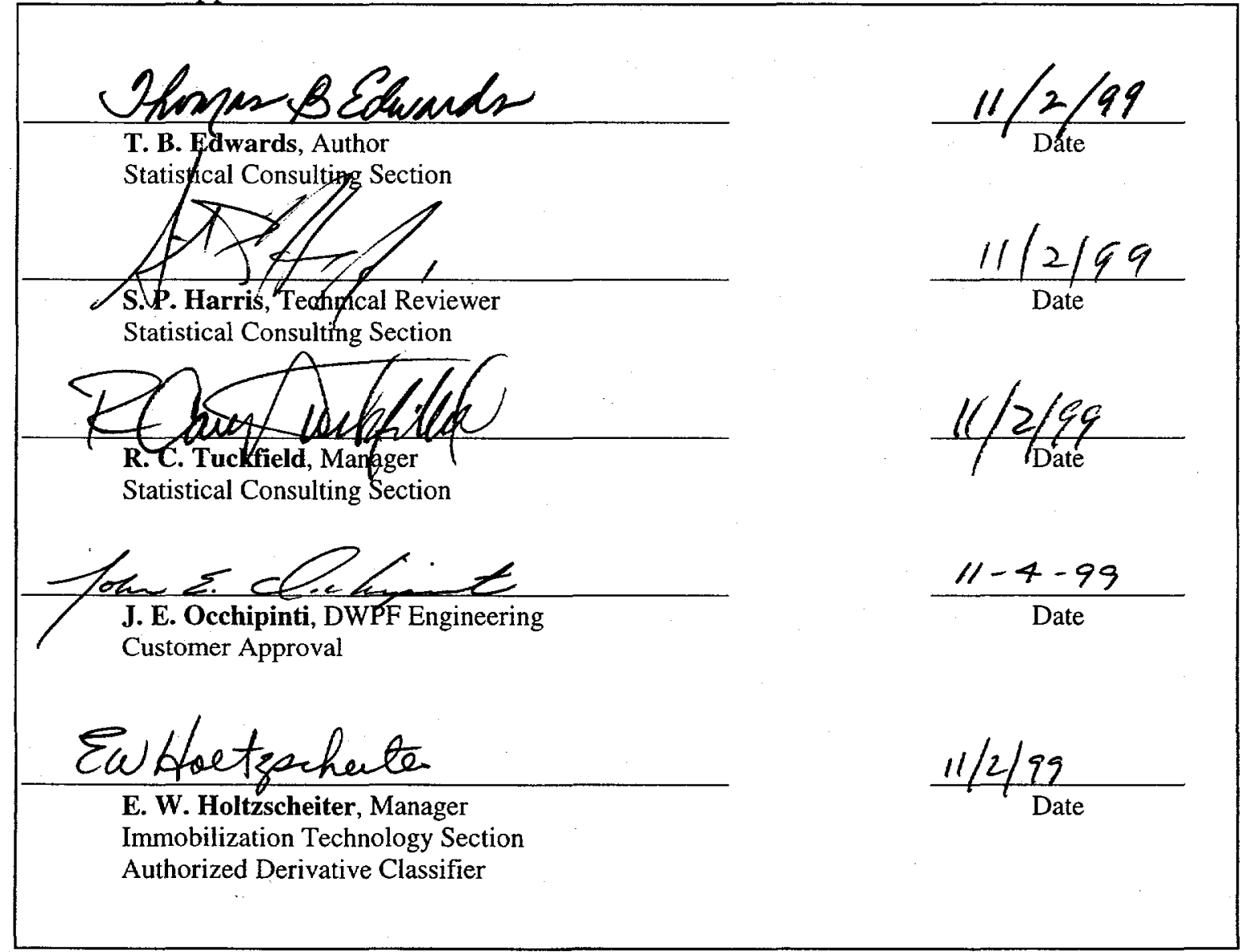


This page intentionally left blank. 


\section{ABSTRACT}

The Defense Waste Processing Facility (DWPF) is evaluating new sampling and analytical methods that may be used to support future Slurry Mix Evaporator (SME) batch acceptability decisions. This report uses data acquired during DWPF's processing of macro-batch 1 to determine a set of vitrification factors covering several SME and Melter Feed Tank (MFT) batches. Such values are needed for converting the cation measurements derived from the new methods to a "glass" basis. The available data from macro-batch 1 were used to examine the stability of these vitrification factors, to estimate their uncertainty over the course of a macro-batch, and to provide a recommendation on the use of a single factor for an entire macro-batch.

The report is in response to Technical Task Request HLW/DWPF/TTR-980015. 
This page intentionally left blank. 


\section{CONTENTS}

ABSTRACT $\quad$ v

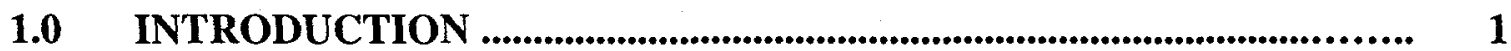

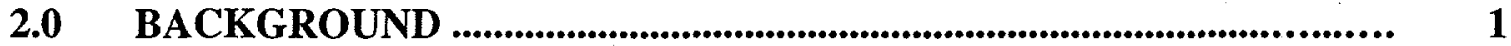

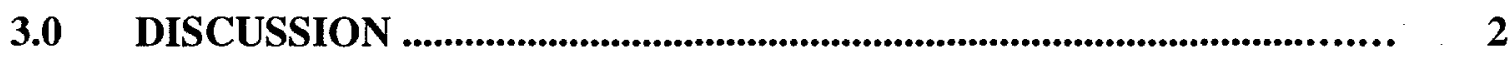

3.1 The Macro-Batch 1 Data ............................................................... 2

3.2 Determination of Vitrification Factors .................................... . 2

3.3 An Evaluation of the Vitrification Factors ........................... 4

3.4 Vitrification Factors Over the Course of a Macro-Batch ...................... 8

4.0 CONCLUDING COMMENTS AND RECOMMENDATIONS ............. 8

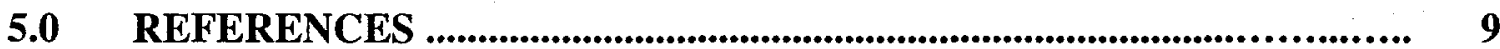

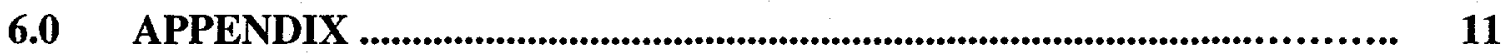


This page intentionally left blank. 
LIST OF TABLES Page

1 Vitrification Factor for Each Sample by Batch-Vessel .................... 3

2 Descriptive Statistics for Vitrification Factors ....................................... 8

LIST OF FIGURES

Page

$1 \quad$ An Overview of the Sample Weights Taken

2

$2 \mathrm{R}$ and $\mathrm{X}$-bar Charts for the Vitrification Factor by Batch for the SME

4

$3 \quad \mathrm{R}$ and X-bar Charts for the Vitrification Factor by Batch for the MFT

5

4 Control Charts for the Individual Vitrification Factor by SME Batch and for the Moving Range

6

5

Control Charts for the Individual Vitrification Factor by MFT Batch and for the Moving Range 
This page intentionally left blank. 


\subsection{INTRODUCTION}

As the Defense Waste Processing Facility (DWPF) processed the later batches of macro-batch 1, data were being collected on new sampling and analytical methods proposed for future support of Slurry Mix Evaporator (SME) batch acceptability decisions. Today, under production conditions, this acceptability is judged based upon data derived from vitrified SME samples acquired using the Hydragard $\circledast$ sampling system and peanut vials. The new sampling scheme utilizes the Hydragard $\circledast$ but involves the use of $3-\mathrm{mL}$ inserts instead of the $15-\mathrm{mL}$ peanut vials. The new analytical methods (cold chemical and insert fusion) do not rely upon a vitrification step to derive their cation concentration measurements, as do the current production methods (mixed acid and fusion), but they do rely on a vitrification factor that can be used to convert these cation concentration measurements to a "glass" basis.

The cation measurements generated by the new analytical methods need to be converted to a "glass" basis so that they may be used with DWPF's product and process property models. These models, which predict product and process properties critical for SME acceptability decisions, relate these properties to glass composition. Currently, the glass composition for a given SME batch is determined by averaging the compositions of four or more vitrified SME samples. Measurements taken during the normal, production processing of the vitrified samples for a SME batch can be used to determine corresponding vitrification factors. Such measurements were determined using the current, production sampling and analytical procedures for several SME batches, as well as the corresponding batches of the Melter Feed Tank (MFT), processed toward the end of macro-batch 1. These data are the focus of this report. They are to be used to investigate the potential stability of these vitrification factors over the production batches making up a macro-batch and to determine the feasibility of using a single value for this factor over an entire macro-batch.

The report is in response to Technical Task Request HLW/DWPF/TTR-980015 [1] and is one of the deliverables described in the associated Task Technical and QA Plan [2].

\subsection{BACKGROUND}

Testing of the new sampling and analytical procedures versus the production methods was conducted under simulated conditions in the mock-up facility at DWPF, and the results were reported and analyzed in references $[3,4]$. The cation concentration measurements derived from the cold chemical procedure were expressed as weight fractions or weight percents of the solution weight of the sample. These values were then converted to calcined weight using a factor derived from the insert samples that were analyzed via the modified fusion method. The cation concentrations derived from these insert fusion samples were also expressed relative to calcine weight. Average cation concentrations computed from cold chemical and modified fusion values (on a calcine basis) were taken as representative of these concentrations in the corresponding glass form.

The analyses of the data generated by these tests $[3,4]$ led to modifications of the cold chemical and insert fusion procedures $[5,6]$. One such modification dealt with the use of an additional conversion factor. This factor was determined using the current vitrification procedures for other representative samples of the material being processed along with the new sampling and analytical methods. Since the mock-up tests were conducted in a parallel manner, old-versus-new, representative samples were readily available, and their analyses, conducted using the vitrification methods, facilitated the study of impact of this additional conversion factor on the DWPF operability window [7].

As a step along the way toward implementation of the new sampling and analytical procedures, there is a need to explore the vitrification factor for a DWPF macro-batch over several production batches. Macro-batch 1 provides an opportunity for such an investigation. Even though the new procedures were not implemented during this macro-batch, data captured during its processing provide an opportunity to investigate an aspect of the vitrification factor not offered by the mock-up testing, specifically, the variation of this factor due to differences in the material from batch to batch. These differences stem from the less-than-perfect uniformity of the sludge coming from Tank 51 and from 
variations in processing such as the blending of this sludge and the frit. The simulant used for the mock-up testing remained the same over all runs; the only contributors to the variation of the vitrification factors over these runs were sampling and analytical. There was no variation due to variation in material from one production batch to the other. The data from macro-batch 1 provide an opportunity to assess the impact of this additional source of variation in the uncertainty of the corresponding vitrification factor.

\subsection{DISCUSSION}

In this section, the data from several recent production batches from macro-batch 1 are presented and reviewed. These data were acquired during the processing of samples taken from the SME and from the MFT over production batches 77 through 92 .

\subsection{THE MACRO-BATCH I DATA}

The macro-batch 1 data available for this study that were received from the DWPF are provided in Table A.1 in the Appendix. These data involve various weights of samples taken from the SME and MFT over several production batches. The progression of weights for each sample is illustrated in Figure 1.

Figure 1: An Overview of the Sample Weights Taken

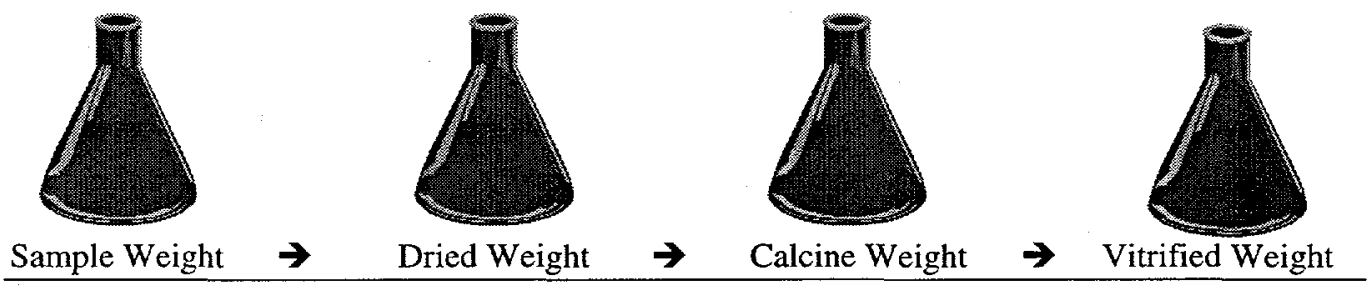

These weights are presented in grams ( $\mathrm{g}$ ) in Table A.1, and the dried, calcine, and vitrified weights are also expressed as weight percents of the corresponding sample weights.

Exhibit A.1in the Appendix provides a look at these weight percent measurements for each vessel and production batch. This exhibit provides plots of these data over the production batches for both the SME and MFT. The means and standard deviations for dried weight percent, calcine weight percent, and vitrified weight percent and other descriptive statistics for the SME and MFT are presented in Exhibit A.2.

The percent coefficient of variation (CV), the sample standard deviation as a percent of the corresponding sample mean, is provided under each the "Moments" section of this exhibit. The values for the MFT are consistently higher than their counterparts in the SME, indicating more variability in samples from the MFT than samples from the SME for these measurements.

\subsection{DETERMINATION OF VITRIFICATION FACTORS}

The data presented in Table A.1 can be used to determine a vitrification factor for each sample for each production batch for each vessel. Since this factor is to be used to convert cation concentrations that are expressed as dried weight percents (fractions) to "glass" weight percents (fractions), the ratio of dried to vitrified weights from Table A.1 is of primary interest. ${ }^{\text {' Exhibit }}$ A. 3 provides a look the correlations among the dried, calcine, and vitrified weight percents for all of the samples. In addition, scatter plots of these results are also provided in this exhibit. A closer look at the relationship between the dried weight percent versus vitrified weight percent values is provided in Exhibit A.4. In this exhibit, the results of a regression of the dried wt\%

The weight percents, instead of the actual weights, can be used since both weight percents are determined relative to the sample weight; i.e., the ratios of the two weights and the two weight percents are algebraically equivalent. 
values on their corresponding vitrified wt\% values are provided. These values are presented in Table 1.

Table 1:Vitrification Factor for Each Sample by Batch-Vessel

\begin{tabular}{|c|c|c|c|c|c|}
\hline Batch-Vessel & Vit Factor & Batch-Vessel & Vit Factor & Batch-Vessel & Vit Factor \\
\hline 77-SME & 1.1493 & 83-SME & 1.1452 & 88-SME & 1.1472 \\
\hline 77-SME & 1.1504 & 83-SME & 1.2212 & 88-SME & 1.1482 \\
\hline 77-SME & 1.1497 & 83-SME & 1.1478 & 88-SME & 1.1465 \\
\hline 77-SME & 1.1539 & 83-SME & 1.1442 & 88-SME & 1.1482 \\
\hline 77-SME & 1.1541 & 83-SME & 1.1445 & 88-SME & 1.1631 \\
\hline 77-SME & 1.1477 & 83-SME & 1.1434 & 88-SME & 1.1533 \\
\hline 77-MFT & 0.5698 & 83-MFT & 1.1609 & 88-MFT & 1.1449 \\
\hline 77-MFT & 1.1450 & 83-MFT & 1.1771 & 88-MFT & 1.1375 \\
\hline 77-MFT & 1.1445 & 83-MFT & 1.1576 & 88-MFT & 1.1413 \\
\hline 77-MFT & 1.1392 & 83-MFT & 1.2248 & 88-MFT & 1.1416 \\
\hline 77-MFT & 1.1434 & 83-MFT & 1.1562 & 88-MFT & 1.1479 \\
\hline 77-MFT & 1.1496 & 83-MFT & 1.1625 & 88-MFT & 1.1396 \\
\hline 78-SME & 1.1417 & 84-SME & 1.1406 & 89-SME & 1.1432 \\
\hline 78-SME & 1.1448 & 84-SME & 1.1428 & 89-SME & 1.1400 \\
\hline 78-SME & 1.1634 & 84-SME & 1.1406 & 89-SME & 1.1410 \\
\hline 78-SME & 1.1408 & 84-SME & 1.1407 & 89-SME & 1.1268 \\
\hline 78-SME & 1.1472 & 84-SME & 1.1411 & 89-SME & 1.1544 \\
\hline 78-SME & 1.1 .448 & 84-SME & 1.1432 & 89-SME & 1.1401 \\
\hline 78-MFT & 1.1542 & 84-MFT & 1.1669 & 89-MFT & 1.1415 \\
\hline 78-MFT & 1.1493 & 84-MFT & 1.1615 & 89-MFT & 1.1477 \\
\hline 78-MFT & 1.1513 & 84-MFT & 1.1515 & 89-MFT & 1.1412 \\
\hline 78-MFT & 1.1595 & 84-MFT & 1.1548 & 89-MFT & 1.1429 \\
\hline 78-MFT & 1.1450 & 84-MFT & 1.2704 & 89-MFT & 1.1442 \\
\hline 78-MFT & 1.1428 & 84-MFT & 1.1612 & 89-MFT & 1.1487 \\
\hline 79-SME & 1.1577 & 85-SME & 1.1414 & 90-SME & 1.1464 \\
\hline 79-SME & 1.1569 & 85-SME & 1.1469 & 90-SME & 1.1432 \\
\hline 79-SME & 1.1532 & 85-SME & 1.1480 & 90-SME & 1.1522 \\
\hline 79-SME & 1.1508 & 85-SME & 1.1454 & 90-SME & 1.1362 \\
\hline 79-SME & 1.1424 & 85-SME & 1.1466 & 90-SME & 1.1436 \\
\hline 79-SME & 1.1472 & 85-SME & 1.1477 & 90-SME & 1.1461 \\
\hline 80-SME & 1.1419 & 85-MFT & 1.1488 & 90-MFT & 1.1353 \\
\hline 80-SME & 1.1387 & 85-MFT & 1.1421 & 90-MFT & 1.1453 \\
\hline 80-SME & 1.1420 & 85-MFT & 1.1419 & 90-MFT & 1.1466 \\
\hline 80-SME & 1.1389 & 85-MFT & 1.1525 & 90-MFT & 1.1427 \\
\hline 80-SME & 1.1442 & 85-MFT & 1.1467 & 90-MFT & 1.1424 \\
\hline 80-SME & 1.1401 & 85-MFT & 1.1593 & 90-MFT & 1.1416 \\
\hline 81-SME & 1.1432 & 86-SME & 1.1478 & 92-SME & 1.1798 \\
\hline 81-SME & 1.1449 & 86-SME & 1.1421 & 92-SME & 1.1957 \\
\hline 81-SME & 1.1452 & 86-SME & 1.1463 & 92-SME & 1.1796 \\
\hline 81-SME & 1.1409 & 86-SME & 1.1507 & 92-SME & 1.1739 \\
\hline 81-SME & 1.1442 & 86-SME & 1.1338 & 92-SME & 1.1743 \\
\hline 81-SME & 1.1448 & 86-SME & 1.1495 & 92-SME & 1.1858 \\
\hline 81-MFT & 2.5348 & 86-MFT & 1.1371 & 92-MFT & 1.1629 \\
\hline 81-MFT & 2.2075 & 86-MFT & 1.1467 & 92-MFT & 1.1563 \\
\hline 81-MFT & 1.9489 & 86-MFT & 1.1445 & 92-MFT & 1.1458 \\
\hline 81-MFT & 1.6136 & 86-MFT & 1.1450 & 92-MFT & 1.1661 \\
\hline 81-MFT & 3.1494 & 86-MFT & 1.1460 & 92-MFT & 1.1620 \\
\hline 81-MFT & 2.1467 & 86-MFT & 1.1476 & 92-MFT & 1.1657 \\
\hline 82-SME & 1.1364 & 87-SME & 1.1404 & & \\
\hline 82-SME & 1.1371 & 87-SME & 1.1413 & & \\
\hline 82-SME & 1.1384 & 87-SME & 1.1449 & & \\
\hline 82-SME & 1.1364 & 87-SME & 1.1474 & & \\
\hline 82-SME & 1.1341 & 87-SME & 1.1379 & & \\
\hline 82-SME & 1.1326 & 87-SME & 1.1481 & & \\
\hline 82-MFT & 1.1412 & & & & \\
\hline 82-MFT & 1.1435 & & & & \\
\hline 82-MFT & 1.1392 & & & & \\
\hline 82-MFT & 1.1444 & & & & \\
\hline 82-MFT & 1.1425 & & & & \\
\hline 82-MFT & 1.1389 & & & & \\
\hline
\end{tabular}




\subsection{AN EVALUATION OF THE VITRIFICATION FACTORS}

A first look at these vitrification factors determined from the SME data is provided in Figure 2. In this exhibit, $\overline{\mathrm{x}}$ and range (R) control chart are provided for the vitrification factors by batch for the SME vessel. The range chart indicates an out-of-control situation for the variability of batch 92. Out-of-control situations for the batch averages of these values are indicated for batches $80,82,84$, and 92 .

Figure 2: R and X-bar Charts for the Vitrification Factor by Batch for the SME

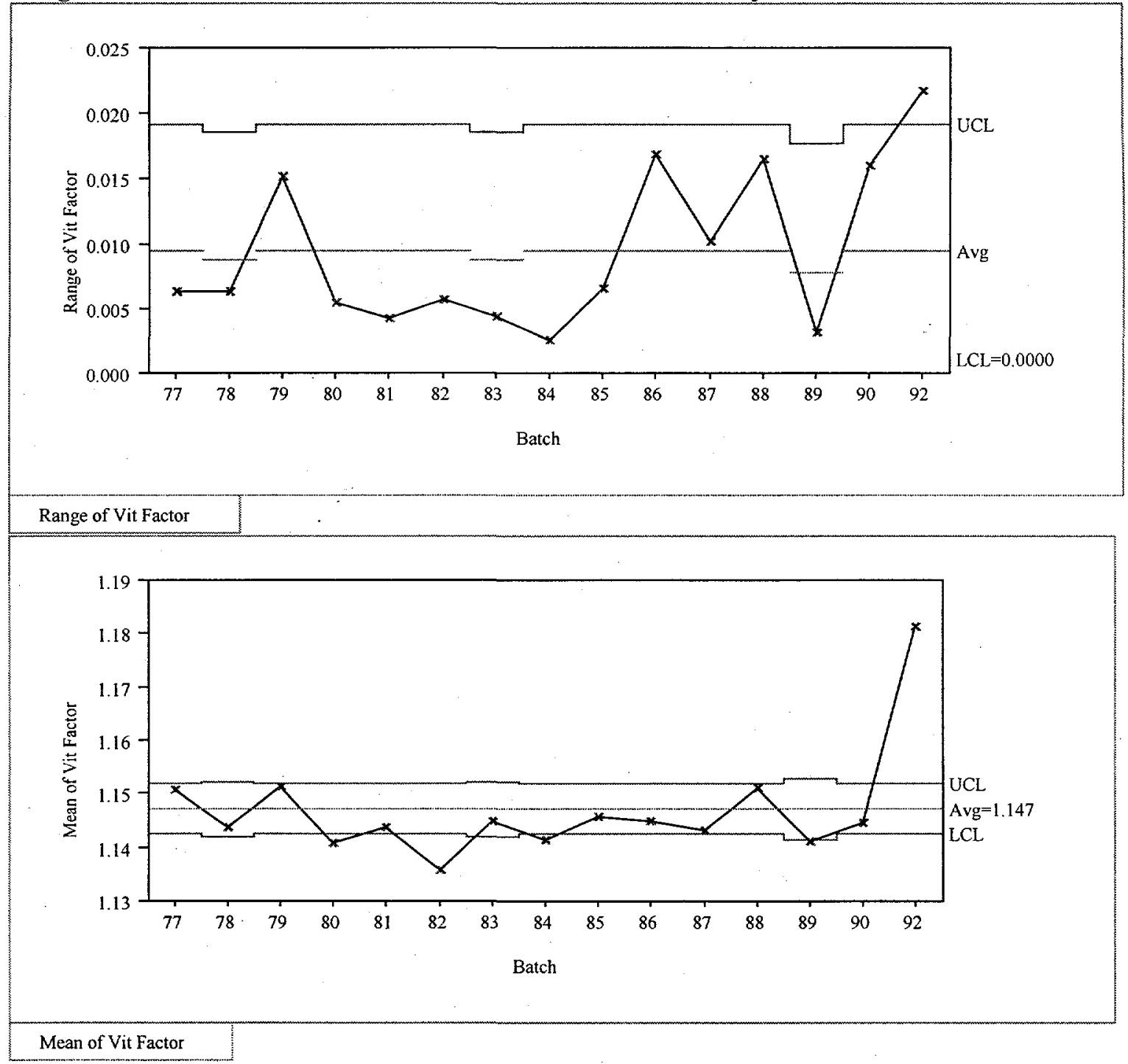


A first look at these vitrification factors determined from the MFT data is provided in Figure 3. In this exhibit, range $(R)$ and $\bar{x}$ control charts are provided for the vitrification factors by batch for the MFT vessel. The range chart indicates no out-of-control situations. Out-of-control situations for the batch averages of these values are indicated for batches $82,83,84,87$, and 92 .

Figure 3: $R$ and X-bar Charts for the Vitrification Factor by Batch for the MFT

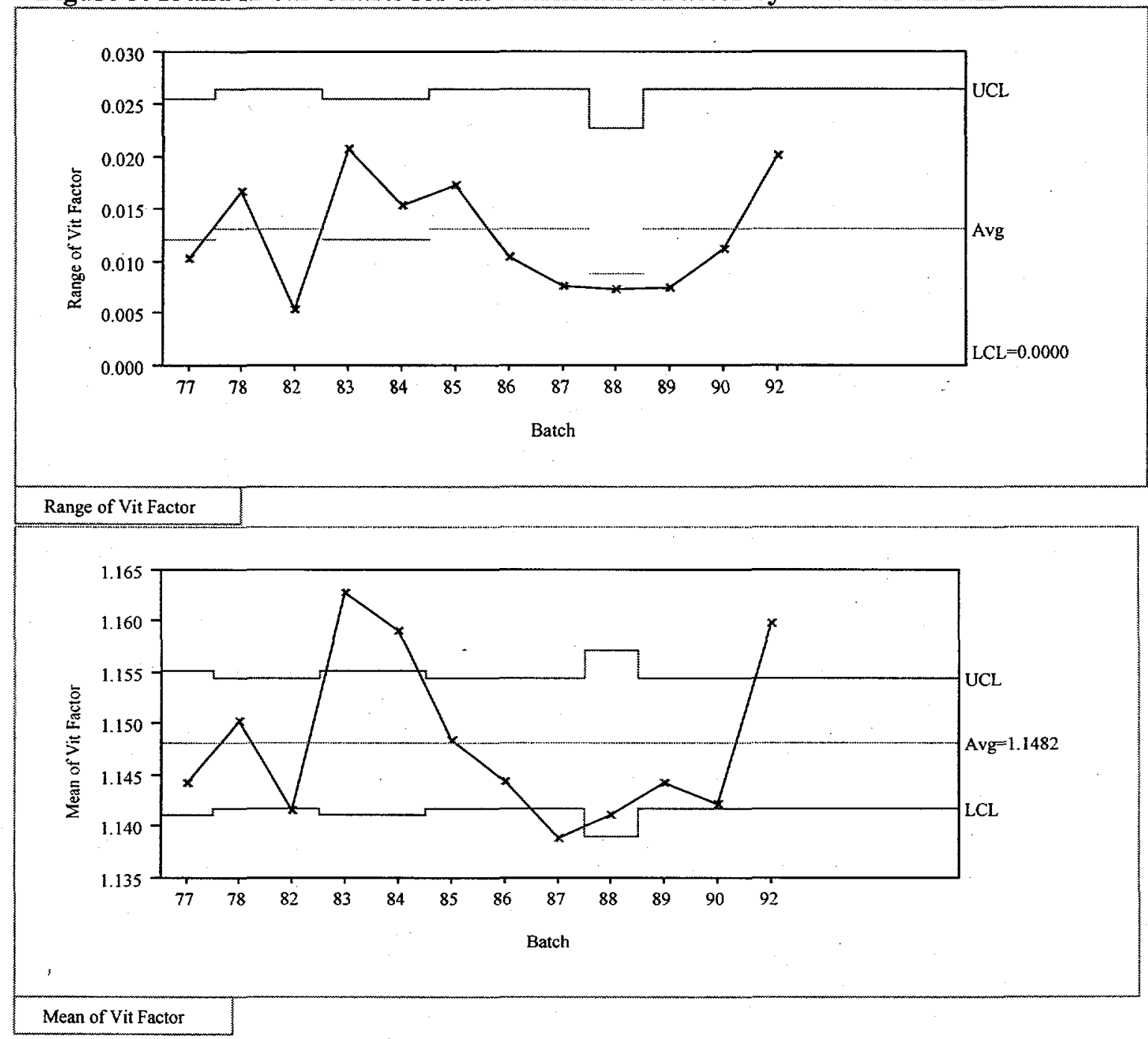

The results of Figures 2 and 3 indicate that these processes are not in a state of statistical control. A contributing factor to this large number of out of control situations is related to the development of the control limits for these charts (i.e., the use of the samples from a single SME or MFT batch as the sub-group representing these processes). For each vessel, the control limits are determined using the variability within the samples from each batch. The variability among the vitrification factors determined from the samples of one batch is smaller (on average) than the variation between the batches. This between batch variation is not included in the development of the control limits (i.e., it is not captured in the samples from a single batch, the sub-groups used to determine these limits). Thus, the control limits determined from these subgroups of the process are not appropriate for judging statistical stability.

To capture the between batch variation in the development of the control limits, an additional set of charts was prepared. Computing the average vitrification factor for each batch and 
developing an individuals control chart for the resulting values leads to Figures 4 and 5 for the SME and MFT, respectively. Figure 4 also includes a moving range chart for the SME values, and a moving range chart for the MFT data is included in Figure 5.

Figure 4: Control Charts for the Individual Vitrification Factor by SME Batch and for the Moving Range

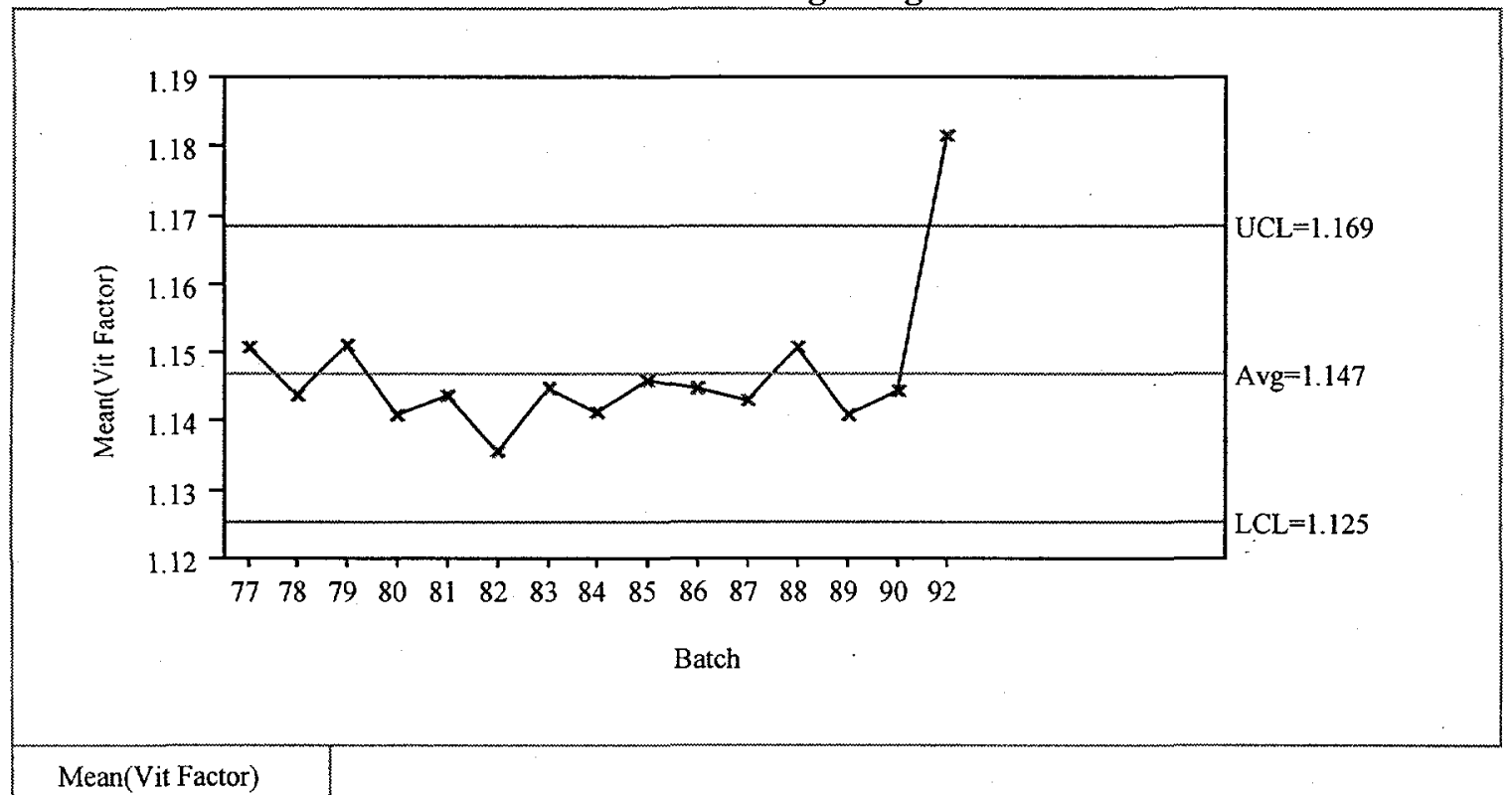

Mean(Vit Factor)

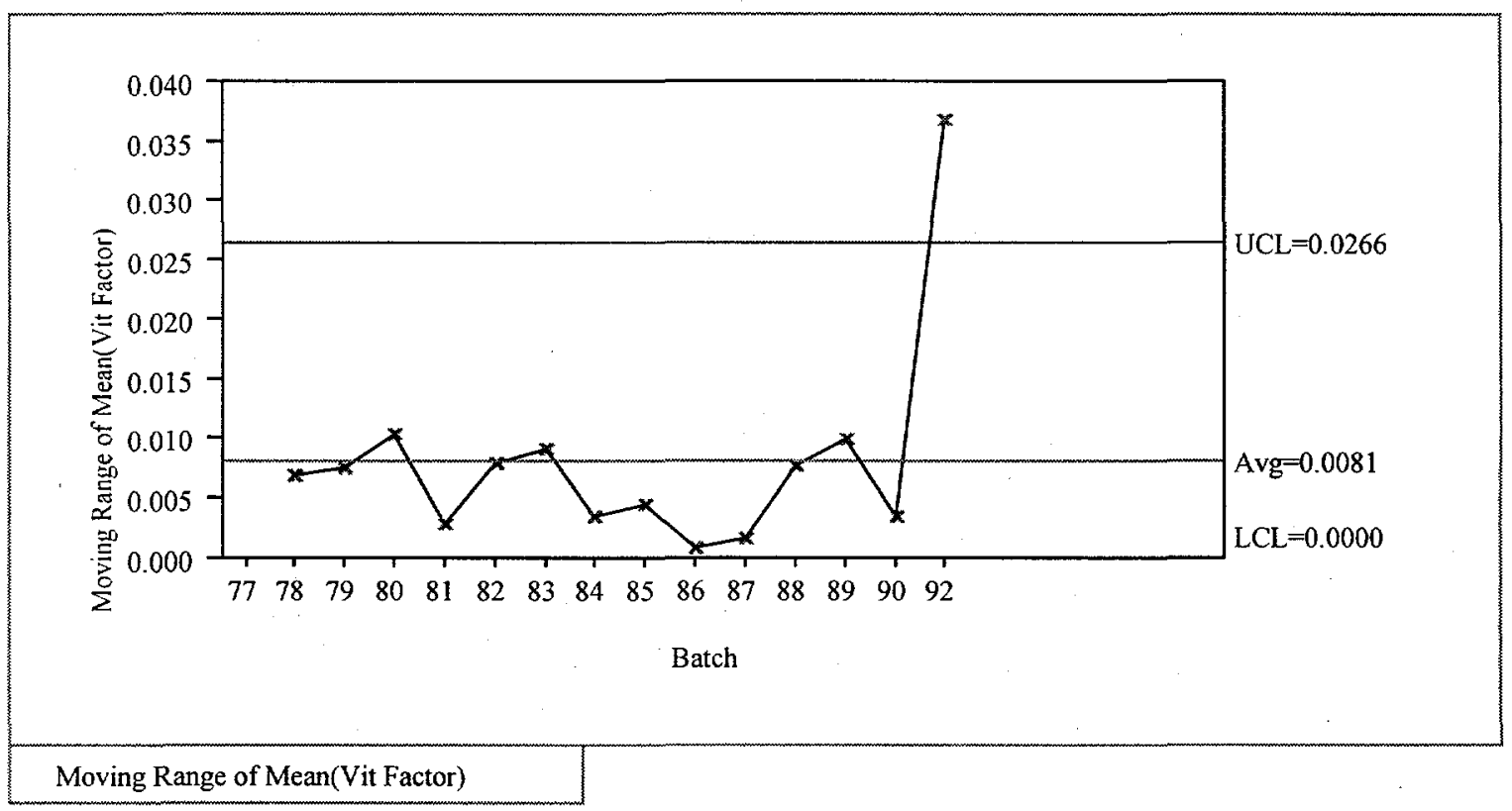


Figure 5: Control Charts for the Individual Vitrification Factor by MFT Batch and for the Moving Range

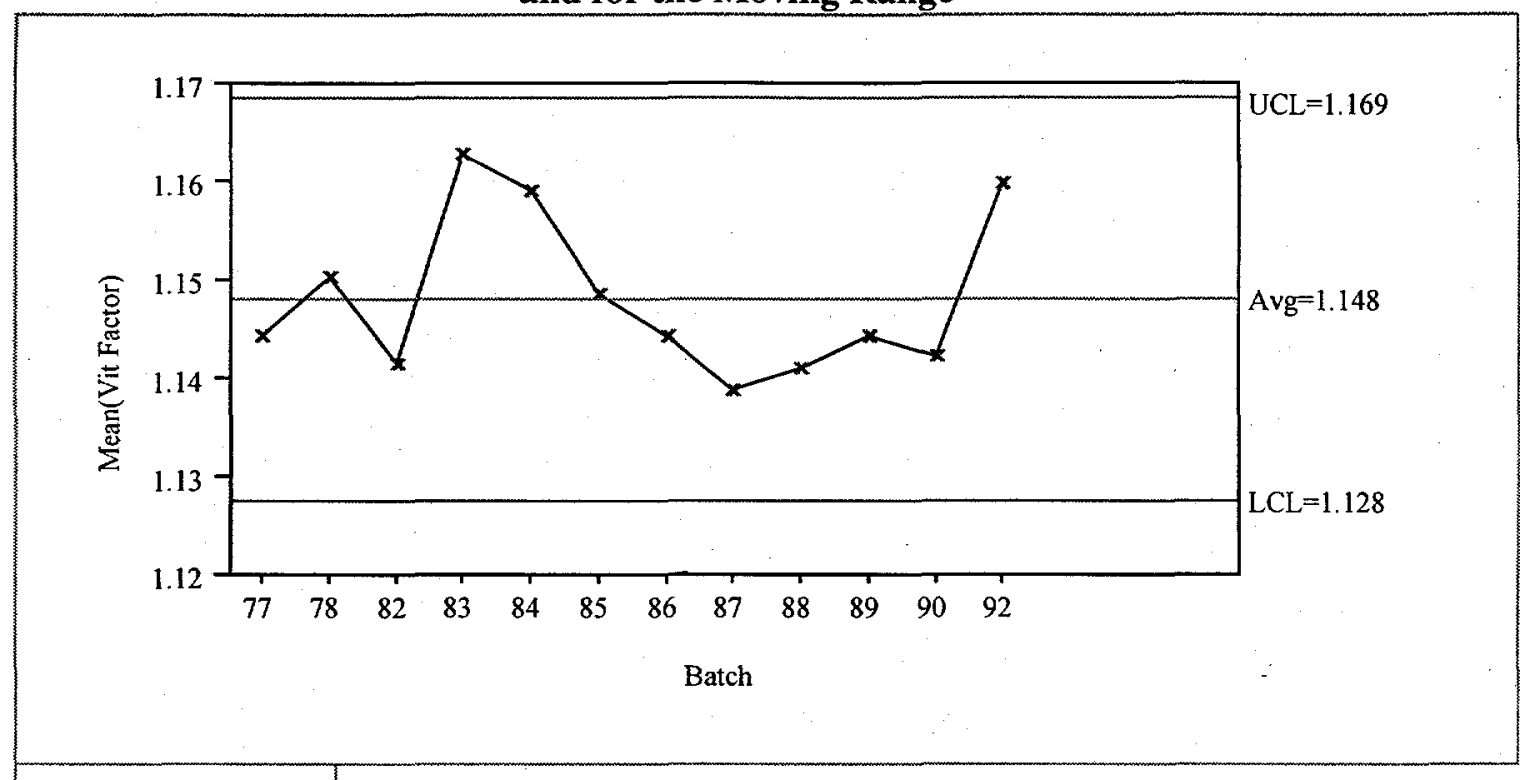

Mean(Vit Factor)

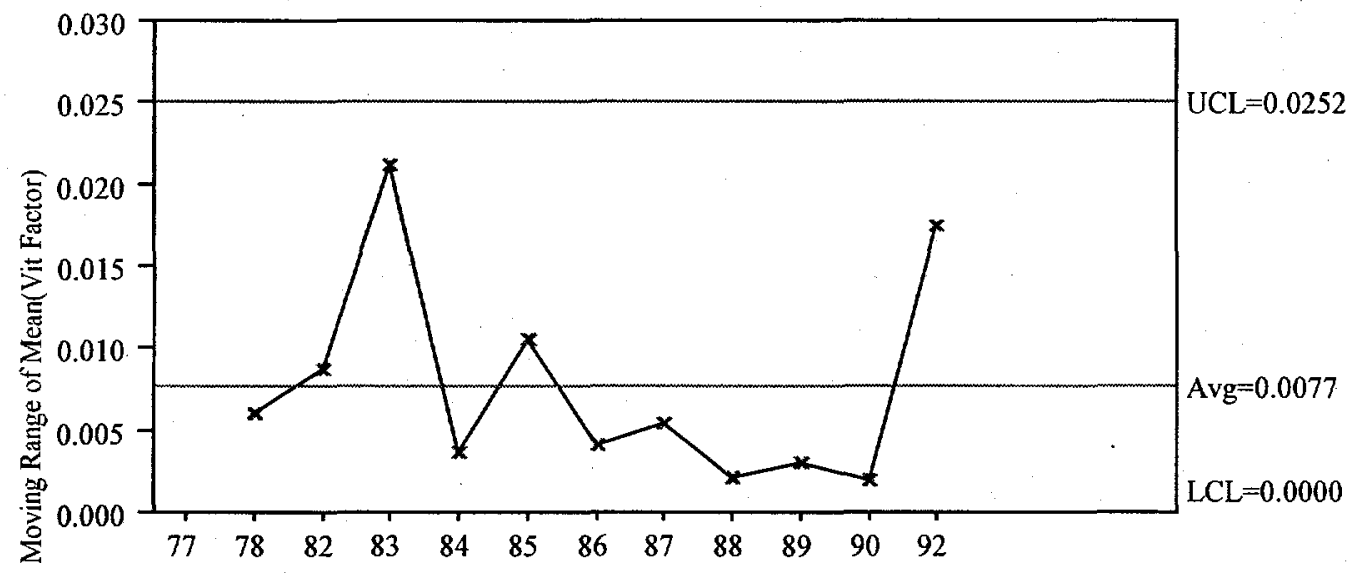

Batch

Moving Range of Mean(Vit Factor)

Figure 4 reveals only one batch, batch 92, outside of the 3-sigma limits for the SME results with no MFT batches out of control for Figure 5. A closer look at all of the available SME vitrification factors and in particular those for batch 92 is provided in Exhibit A.4 in the Appendix. There is no indication of an outlier among the values for batch 92; each of which are larger than all of the values determined for the other batches. The statistical tests presented in Exhibit A.4 indicate statistically significant (at the 5\% significance level) differences among the means and variances of the vitrification factors across the SME batches. 
The descriptive statistics for the vitrification factors for the SME and the MFT are summarized in Table 2. Unless there is an assignable cause for the out of control situation indicated at the batch 92 results, the results from this batch should be included in the statistics representing the vitrification factor. Thus, these results are included in the summary information shown in Table 2 .

Table 2: Descriptive Statistics for Vitrification Factors

\begin{tabular}{|c|c|c|c|c|}
\hline Including Batch 92 & $\begin{array}{c}\text { Sample } \\
\text { Size }\end{array}$ & Mean & $\begin{array}{c}\text { Standard } \\
\text { Deviation }\end{array}$ & $\begin{array}{c}\text { \% Coefficient of } \\
\text { Variation }\end{array}$ \\
\hline MFT & 12 & 1.1482 & 0.00815 & 0.70951 \\
\hline SME & 15 & 1.1471 & 0.01041 & 0.90765 \\
\hline
\end{tabular}

\subsection{VITRIFICATION FACTORS OVER THE COURSE OF A MACRO-BATCH}

Using the information from Table 2 and assuming that the vitrification factors for the production batches over a macro-batch follow (approximately) a normal distribution, then a tolerance interval approach can be used to bound the factors likely for these production batches. This leads to the following interval that provides coverage for $95 \%$ of the production batches with $95 \%$ confidence

$$
\overline{\mathrm{X}} \pm \mathrm{Ks}=1.1471 \pm 2.954(0.01041)=1.1471 \pm 0.03075
$$

$(1.11635,1.17785)$

Or expressing this interval relative to the average value, the tolerance statement becomes

$$
1.1471 \pm 2.681 \% \text {. }
$$

Note that (from Exhibit A.1) the vitrification factor value for SME batch 92, 1.1815, is not within this tolerance interval. This reflects the out of control situation for the batch, provides a strong indication of a lack of normality for these values, and echoes the need to identify a special cause for the results from this batch. When a special cause is identified, steps must be taken to eliminate this cause or mitigate its effect. Without an understanding of the cause for the larger than expected value for batch 92 , there is an indication of a lack of predictability for the vitrification factors that might be encountered over the course of a processing a macro-batch. This lack of predictability precludes the use a single vitrification factor for a macro-batch leading to the need to develop such a factor for each SME batch.

\subsection{CONCLUDING COMMENTS AND RECOMMENDATIONS}

This report used data from DWPF's macro-batch 1 to evaluate the vitrification factors needed for the conversion of cold chemical and insert fusion cation measurements. The available data were used to examine the stability of these values, to estimate their uncertainty over the course of a macro-batch, and to provide a recommendation on the use of a single factor for an entire macro-batch.

The data from one SME production batch (batch 92) indicated an out-of-control situation for the vitrification factor corresponding to this batch as compared to the other available data. The processing of and results from this batch need to be reviewed by DWPF Engineering to identify the reason(s) or assignable cause(s) for this behavior. If no such resolution for the batch 92 results is forthcoming, it is recommended that, in future testing of the new sampling and analytical methods, a vitrification factor be determined for each SME batch and that this factor be used to convert the resulting cation concentrations to a glass basis. 


\subsection{REFERENCES}

[1] DWPF Engineering, Task Technical Request HLW/DWPF/TTR-980015, March 18, 1998.

[2] Edwards, T. B., "Task Technical \& QA Plan: The Conversion of Cold Chemical and Insert Fusion Concentration Measurements Using a Vitrification Factor", WSRC-RP-98-00150, April 2, 1998.

[3] Harris, S. P., "DWPF Sample Vial Insert Study: Statistical Analysis of DWPF Mock-up Test Data (U)," WSRC-TR-97-00292, September 18, 1997.

[4] Reeve, C. P., "Covariance Matrices for Direct Dissolution of Vial Insert Samples in DWPF Mock-up Facility (U),"WSRC-TR-97-00286, Rev. 1, February 20, 1998.

[5] Beck, R. S. "Review of Statistical Analyses Resulting From Performance of HLWD-DWPF-005(U)," WSRC-RP-97-00883, September 29, 1997.

[6] Beck, R. S. "Resolution of Error Sources in Proposed Lab Aliquoting Methods (U)," WSRC-RP-98-00053, February 23, 1998.

[7] Edwards, T. B., "The Conversion of Cold Chemical and Insert Fusion Cation Measurements using a Vitrification Factor (U)," WSRC-TR-98-00219, Revision 0, June 15, 1998.

[8] Brown, K. G. and R. L. Postles, "SME Acceptability Determination for DWPF Process Control (U)," WSRC-TR-95-0364, Rev. 3, February 21, 1996.

[9] SAS Institute, JMP ${ }^{\circledR}$ : Statistics and Graphics Guide, Version 3.0, SAS Institute, Inc., Cary, NC, 1994. 
This page intentionally left blank. 


\subsection{APPENDIX}

Page

Number

Table A.1: Macro-Batch 1A Sample Weights ............................................... A1

Exhibit A.1: Plots of Sample Weights by Batch and Vessel ............................................ A7

Exhibit A.2: Descriptive Statistics for the Sample Weights by Vessel ...................................... A9

Exhibit A.3: Correlations and Scatter Plots of Sample Weight Percents .................................... Al1

Exhibit A.4: Analysis of Vitrification Factors by Batch for the SME ...................................... A13 
This page intentionally left blank. 


\begin{tabular}{|c|c|c|c|c|c|c|c|c|c|c|c|c|c|c|c|c|}
\hline $\begin{array}{l}\text { Print } \\
\text { Row ID }\end{array}$ & $\begin{array}{l}\text { Batch- } \\
\text { Vessel }\end{array}$ & Vessel & Batch & LIMS \# & $\begin{array}{l}\text { Empty } \\
\text { Plaúnum } \\
\text { wt (g) }\end{array}$ & $\begin{array}{l}\text { Vial } \\
\text { ID }\end{array}$ & $\begin{array}{c}\text { Empty } \\
\text { Vial + Cap } \\
\text { wt (g) }\end{array}$ & $\begin{array}{l}\text { Filled } \\
\text { wt (g) }\end{array}$ & Zr ID & $\begin{array}{c}\text { Empty } \\
\mathrm{Zrwt}(\mathrm{g})\end{array}$ & $\begin{array}{c}\text { Dried } \\
\text { Vial }+\mathrm{Zr} \\
\text { wt (g) }\end{array}$ & $\begin{array}{c}\text { Calc } \\
\text { wt (g) }\end{array}$ & $\begin{array}{l}\text { Cap } \\
\text { wt (g) }\end{array}$ & $\begin{array}{c}\text { Actual } \\
\text { Vial }+ \text { Cap } \\
\text { wt (g) }\end{array}$ & $\begin{array}{c}\text { Actual } \\
\text { Sample } \\
\text { wt (g) }\end{array}$ & $\begin{array}{l}\text { Total } \\
\text { Dried } \\
\text { wt (g) }\end{array}$ \\
\hline 1 & 77-SME & SME & 77 & 50358 & 90.404 & 277 & 27.0720 & 44.826 & 6 & 59.446 & 82.769 & 23.323 & 3.862 & 27.185 & 17.754 & 99.273 \\
\hline 2 & 77-SME & SME & 77 & 50358 & 89.334 & 279 & 27.1085 & 45.218 & 5 & 54.242 & 77.563 & 23.321 & 3.898 & 27.219 & 18.110 & 98.335 \\
\hline 3 & 77-SME & SME & 77 & 50358 & 96.013 & 276 & 27.1667 & 44.849 & 2 & 54.673 & 78.109 & 23.436 & 4.083 & 27.519 & 17.682 & 104.567 \\
\hline 4 & 77-SME & SME & 77 & 50358 & 86.397 & 291 & 27.2898 & 44.859 & 1 & 56.642 & 80.067 & 23.425 & 3.957 & 27.382 & 17.569 & 95.049 \\
\hline 5 & 77-SME & SME & 77 & 50358 & 87.312 & 350 & 27.0853 & 45.025 & 4 & 56.293 & 79.550 & 23.257 & 3.891 & 27.148 & 17.940 & 96.195 \\
\hline 6 & 77-SME & SME & 77 & 50358 & 90.604 & 349 & 27.2523 & 45.342 & 3 & 53.754 & 77.168 & 23.414 & 3.969 & 27.383 & 18.090 & 99.654 \\
\hline 7 & 77-MFT & MFT & 77 & 50572 & 86.352 & 433 & 27.1830 & 45.372 & 6 & 54.585 & 77.924 & 23.339 & 3.909 & 27.248 & 18.189 & 93.586 \\
\hline 8 & 77-MFT & MFT & 77 & 50572 & 91.947 & 462 & 27.0590 & 45.407 & 5 & 56.087 & 79.319 & 23.232 & 3.914 & 27.146 & 18.348 & 100.683 \\
\hline 9 & 77-MFT & MFT & 77 & 50572 & 90.38 & 466 & 27.0570 & 45.598 & 4 & 58.431 & 81.333 & 22.902 & 3.844 & 26.746 & 18.541 & 99.346 \\
\hline 10 & 77-MFT & MFT & 77 & 50572 & 87.885 & 463 & 27.2640 & 45.075 & 3 & 51.667 & 75.104 & 23.437 & 3.976 & 27.413 & 17.811 & 96.038 \\
\hline 11 & 77-MFT & MFT & 77 & 50572 & 87.56 & 430 & 27.2930 & 45.418 & 2 & 60.965 & 84.414 & 23.449 & 3.933 & 27.382 & 18.125 & 96.194 \\
\hline 12 & 77-MFT & MFT & 77 & 50572 & 90.685 & 464 & 27.2640 & 45.622 & 1 & 58.505 & 81.999 & 23.494 & 3.855 & 27.349 & 18.358 & 99.308 \\
\hline 13 & 78-SME & SME & 78 & 50660 & 91.614 & 612 & 27.0470 & 46.049 & 2 & 60.915 & 84.333 & 23.418 & 3.846 & 27.264 & 19.002 & 101.264 \\
\hline 14 & 78-SME & SME & 78 & 50660 & 87.885 & 622 & 25.8670 & 45.749 & 1 & 58.464 & 80.975 & 22.511 & 3.856 & 26.367 & 19.882 & 7.536 \\
\hline 15 & 78-SME & SME & 78 & 50660 & 91.376 & 616 & 27.1580 & 46.234 & 4 & 58.080 & 81.596 & 23.516 & 3.875 & 27.391 & 19.076 & 00.226 \\
\hline 16 & 78-SME & SME & 78 & 50660 & 90.563 & 620 & 27.1870 & 46.302 & 6 & 54.540 & 78.066 & 23.526 & 3.902 & 27.428 & 19.115 & 100.474 \\
\hline 17 & 78-SME & SME & 78 & 50660 & 91.959 & 613 & 27.2030 & 46.252 & 3 & 51.633 & 75.553 & 23.920 & 3.903 & 27.823 & 19.049 & 101.234 \\
\hline 18 & 78-SME & SME & 78 & 50660 & 89.846 & 618 & 27.1090 & 46.109 & 0 & 57.082 & 81.117 & 24.035 & 3.996 & 28.031 & 19.000 & 8.795 \\
\hline 19 & 78-MFT & MFT & 78 & 50741 & 90.391 & 671 & 27.1840 & 43.992 & No \# & 57.064 & 80.518 & 23.454 & 3.940 & 27.394 & 16.808 & 8.356 \\
\hline 20 & 78-MFT & MFT & 78 & 50741 & 87.898 & 678 & 26.9570 & 45.641 & old $2 *$ & 48.403 & 71.780 & 23.377 & 3.841 & 27.218 & 18.684 & 96.895 \\
\hline 21 & 78-MFT & MFT & 78 & 50741 & 91.958 & 675 & 27.1660 & 46.201 & 3 & 51.632 & 75.069 & 23.437 & 3.950 & 27.387 & 19.035 & 101.067 \\
\hline 22 & 78-MFT & MFT & 78 & 50741 & 87.397 & 676 & 27.8020 & 44.049 & 1 & 58.441 & 82.516 & 24.075 & 3.936 & 28.011 & 16.247 & 95.159 \\
\hline 23 & 78-MFT & MFT & 78 & 50741 & 91.105 & 674 & 27.5270 & 45.981 & 6 & 54.508 & 78.326 & 23.818 & 3.959 & 27.777 & 18.454 & 9.958 \\
\hline 24 & 78-MFT & MFT & 78 & 50741 & 89.862 & 679 & 27.8070 & 45.306 & new 2 * & 60.888 & 84.905 & 24.017 & 3.946 & 27.963 & 17.499 & 98.384 \\
\hline 25 & 79-SME & SME & 79 & 50830 & 91.628 & 987 & 27.0670 & 44.961 & No \# & 50.832 & 74.028 & 23.196 & 3.876 & 27.072 & 17.894 & 100.312 \\
\hline 26 & 79-SME & SME & 79 & 50830 & 96.027 & 986 & 26.9480 & 44.617 & 5 & 55.983 & 79.185 & 23.202 & 3.757 & 26.959 & 17.669 & 104.462 \\
\hline 27 & 79-SME & SME & 79 & 50830 & 91.947 & 982 & 27.5290 & 45.017 & 32 & 52.839 & 76.666 & 23.827 & 3.815 & 27.642 & 17.488 & 100.325 \\
\hline 28 & 79-SME & SME & 79 & 50830 & 89.85 & 981 & 27.0600 & 44.779 & 11 & 54.739 & 77.946 & 23.207 & 3.881 & 27.088 & 17.719 & 98.451 \\
\hline 29 & 79-SME & SME & 79 & 50830 & 91.11 & 983 & 28.0880 & 45.509 & 11-Apr & 58.121 & 82.316 & 24.195 & 3.955 & 28.150 & 17.421 & 9.676 \\
\hline 30 & 79-SME & SME & 79 & 50830 & 87.891 & 988 & 28.2940 & 45.928 & 7 & 54.768 & 79.284 & 24.516 & 3.868 & 28.384 & 17.634 & 6.308 \\
\hline 31 & 80-SME & SME & 80 & 51002 & 84.572 & 421 & 27.8090 & 45.542 & * & 51.584 & 75.689 & 24.105 & 3.815 & 27.920 & 17.733 & 3.149 \\
\hline 32 & 80-SME & SME & 80 & 51002 & 87.272 & 422 & 28.0670 & 45.332 & * & 50.831 & 75.076 & 24.245 & 3.912 & 28.157 & 17.265 & 5.697 \\
\hline 33 & 80-SME & SME & 80 & 51002 & 96.063 & 419 & 27.9910 & 46.092 & * & 57.307 & 81.587 & 24.280 & 3.894 & 174 & 18.101 & 104.570 \\
\hline 34 & 80-SME & SME & 80 & 51002 & 87.425 & 420 & 27.7290 & 45.866 & 11 & 58.151 & 82.193 & 24.042 & 3.792 & 27.834 & 18.137 & 5.852 \\
\hline 35 & 80-SME & SME & 80 & 51002 & 88.333 & 417 & 27.9450 & 45.457 & 32 & 52.855 & 76.974 & 24.119 & 3.881 & 28.000 & 17.512 & 6.809 \\
\hline 36 & 80-SME & SME & 80 & 51002 & 91.124 & 418 & 27.1800 & 45.088 & * & 54.652 & 78.003 & 23.351 & 3.905 & 27.256 & 17.908 & 99.891 \\
\hline 37 & 81-SME & SME & 81 & 51249 & 87.405 & 920 & 27.4580 & 45.259 & 17 & 55.069 & 78.769 & 23.700 & 3.868 & 27.568 & 17.801 & 96.235 \\
\hline 38 & 81-SME & SME & 81 & 51249 & 88 & 924 & 10 & 45.265 & 5 & 56.309 & 295 & 23.986 & 3.931 & 17 & 17.474 & 6.958 \\
\hline 39 & 81-SME & SME & 81 & 51249 & 91.109 & 929 & 28.0020 & 45.419 & 7 & 58.739 & 82.870 & 24.131 & 3.931 & 28.062 & 17.417 & 99.762 \\
\hline 40 & 81-SME & SME & 81 & 51249 & 96.039 & 923 & 28.2230 & 45.519 & 14 & 53.240 & 77.642 & 24.402 & 3.916 & 28.318 & 17.296 & 104.664 \\
\hline 41 & 81-SME & SME & 81 & 51249 & 87.566 & 919 & 28.0150 & 45.566 & 10 & 55.500 & 79.745 & 24.245 & 3.846 & 28.091 & 17.551 & 96.336 \\
\hline 42 & 81-SME & SME & 81 & 51249 & 86.328 & 921 & 27.9860 & 45.603 & 9 & 56.600 & 80.844 & 24.244 & 3.849 & 28.093 & 17.617 & 5.102 \\
\hline 43 & 81-MFT & MFT & 81 & 51366 & 89.858 & 254 & .0300 & 42.210 & 10 & 52.137 & 76.413 & 24.276 & 3.890 & 28.166 & 14.180 & 102.859 \\
\hline 44 & 81-MFT & MFT & 81 & 51366 & 89.035 & 230 & 3.0530 & 45.837 & 14 & 48.808 & 73.101 & 24.293 & 3.860 & 28.153 & 17.784 & 104.130 \\
\hline 45 & 81-MFT & MFT & 81 & 51366 & 91.633 & 260 & 27.6640 & 44.649 & 7 & 56.018 & 79.886 & 23.868 & 3.867 & 27.735 & 16.985 & 105.123 \\
\hline 46 & 81-MFT & MFT & 81 & 51366 & 89.311 & 263 & 27.7140 & 45.820 & 5 & 56.309 & 80.212 & 23.903 & 3.965 & 27.868 & 18.106 & 101.053 \\
\hline 47 & 81-MFT & MFT & 81 & 51366 & 87.565 & 235 & 27.9360 & 43.948 & 4 & 56.716 & 80.884 & 24.168 & 3.857 & 28.025 & 16.012 & 103.652 \\
\hline 48 & 81-MFT & MFT & 81 & 51366 & 88.309 & 219 & 1.4920 & 45.424 & 9 & 54.613 & 78.235 & 23.622 & 3.983 & 27.605 & 17.932 & 103.765 \\
\hline 49 & 2-SME & SME & 82 & 51510 & 91. & 579 & 930 & 45.679 & 4 & 54.710 & .344 & 23.634 & 3.861 & 27.495 & 18.086 & 100.404 \\
\hline 50 & 82-SME & SME & 82 & 51510 & 89.308 & 601 & 2280 & 46.467 & 14 & 48.387 & 72.776 & 24.389 & 3.877 & 28.266 & 18.239 & 8.066 \\
\hline 51 & 82-SME & SME & 82 & 51510 & 89.851 & 580 & 27.4480 & 45.872 & 13 & 44.526 & 68.237 & 23.711 & 3.839 & 27.550 & 18.424 & 8.744 \\
\hline 52 & 82-SME & SME & 82 & 51510 & 88.303 & 586 & 28.3180 & 46.303 & 10 & 51.927 & 76.459 & 24.532 & 3.910 & 28.442 & 17.985 & 7.012 \\
\hline 53 & 2-SME & SME & 82 & 51510 & 87.555 & 603 & 28.1260 & 46.389 & 11 & 50.842 & 75.130 & 24.288 & 3.886 & 28.174 & 18.263 & 6.484 \\
\hline 54 & 2-SME & SME & 82 & 51510 & 89.032 & 584 & 1930 & 46.511 & . & 55.597 & 9.895 & 24.298 & 3.921 & 28.219 & 18.318 & 8.018 \\
\hline 55 & 82-MFT & MFT & 82 & 51615 & 90.373 & 647 & 6190 & 45.049 & 5 & 56.220 & 79.973 & 23.753 & 3.931 & 27.684 & 17.430 & 8.172 \\
\hline 56 & 82-MFT & MFT & 82 & 51615 & 87.452 & 646 & 8.2650 & 44.892 & 16 & 55.030 & 79.442 & 24.412 & 3.917 & 28.329 & 16.627 & 8.814 \\
\hline 57 & 82-MFT & MFT & 82 & 51615 & 86.329 & 648 & 28.2180 & 45.487 & 0 & 58.225 & 82.647 & 24.422 & 3.977 & 28.399 & 17.269 & 4.112 \\
\hline 58 & 82-MFT & MFT & 82 & 51615 & 84.573 & 642 & 28.4310 & 43.051 & 17 & 55.085 & 79.685 & 24.600 & 3.929 & 28.529 & 14.620 & 1.097 \\
\hline 59 & 2-MFT & MFT & 82 & 51615 & 89.942 & 645 & 3.2200 & 44.850 & 0 & 57.468 & 1.941 & 24.473 & 3.869 & 28.342 & 16.630 & 87.327 \\
\hline 60 & -MFT & MFT & 82 & 51615 & 91.091 & 649 & 370 & 44.849 & 9 & 54.143 & .841 & 23.698 & 3.823 & 27.521 & 17.412 & 8.543 \\
\hline 61 & 83-SME & SME & 83 & 51654 & 90.3 & 183 & .5700 & 46.089 & 8 & 56.391 & 81.104 & 24.713 & 3.896 & 28.609 & 17.519 & 8.589 \\
\hline 62 & 83-SME & SME & 83 & 51654 & 89.861 & 174 & 27.7440 & 45.739 & 1 & 53.005 & 76.906 & 23.901 & 3.896 & 27.797 & 17.995 & 98.450 \\
\hline 63 & 83-SME & SME & 83 & 51654 & 89.031 & 170 & 27.7690 & 45.073 & 3 & 53.382 & 77.364 & 23.982 & 3.879 & 27.861 & 17.304 & 97.269 \\
\hline 64 & 83-SME & SME & 83 & 51654 & 84.588 & 172 & 28.0810 & 45.890 & 13 & 58.311 & .535 & 24.224 & 3.925 & 28.149 & 17.809 & 93.087 \\
\hline 65 & -SME & SME & 83 & 51654 & 87.882 & 994 & 27.7470 & 45.829 & 2 & 58.722 & 82.684 & 23.962 & 3.869 & 27.831 & 18.082 & 96.461 \\
\hline 66 & ME & SME & 83 & 51654 & 91.63 & 176 & 28.2450 & 45.955 & 15 & 57.237 & 81.694 & 24.457 & 3.865 & 28.322 & 17.710 & 100.019 \\
\hline 67 & 83-MFT & MFT & 83 & 51744 & 87.613 & 277 & 27.5090 & 45.077 & 2 & 58.695 & 2.835 & 24.140 & 3.907 & 28.047 & 17.568 & 94.733 \\
\hline
\end{tabular}




\begin{tabular}{|c|c|c|c|c|c|c|c|c|c|c|c|c|c|c|c|c|}
\hline \multirow[b]{2}{*}{$\begin{array}{c}\text { Print } \\
\text { Row ID }\end{array}$} & \multirow[b]{2}{*}{ Batch- } & \multirow[b]{2}{*}{ Vessel } & \multirow[b]{2}{*}{ Batch } & \multirow[b]{2}{*}{ LIMS \# } & \multirow{2}{*}{$\begin{array}{c}\text { Empty } \\
\text { Platinum } \\
\text { wt (g) }\end{array}$} & & Empty & & & & Dried & & & Actual & ctual & Total \\
\hline & & & & & & $\begin{array}{l}\text { Vial } \\
\text { ID }\end{array}$ & $\begin{array}{c}\text { Vial + Cap } \\
\text { wt (g) }\end{array}$ & $\begin{array}{l}\text { Filled } \\
\text { wt }(g)\end{array}$ & $\mathrm{Zr}$ ID & $\begin{array}{c}\text { Empty } \\
\text { Zr wt (g) }\end{array}$ & $\begin{array}{l}\text { Vial }+\mathrm{Zr} \\
\text { wt (g) }\end{array}$ & $\begin{array}{c}\text { Calc } \\
\text { wt }(g)\end{array}$ & $\begin{array}{l}\text { Cap } \\
\text { wt (g) }\end{array}$ & $\begin{array}{c}\text { Vial + Cap } \\
\text { wt (g) }\end{array}$ & $\begin{array}{c}\text { Sample } \\
\text { wt (g) }\end{array}$ & $\begin{array}{l}\text { Dried } \\
\text { wt }(g)\end{array}$ \\
\hline 68 & 83-MFT & MFT & 83 & $3 \quad 51744$ & 91.82 & 194 & 28.5660 & 44.310 & 3 & 53.966 & 78.247 & 24.281 & 4.010 & 28.291 & 15.744 & 98.388 \\
\hline 69 & 83-MFT & MFT & 83 & 51744 & 84.614 & 204 & 28.3580 & 44.061 & 8 & 56.380 & 81.259 & 24.879 & 3.947 & 28.826 & 15.703 & 91.069 \\
\hline 70 & 83-MFT & MFT & 83 & 51744 & 90.334 & $291(1)$ & 27.5820 & 43.832 & 1 & 52.975 & 76.829 & 23.854 & 3.980 & 27.834 & 16.250 & 95.292 \\
\hline 71 & 83-MFT & MFT & 83 & 51744 & 89.903 & 297 & 28.4120 & 45.376 & 0 & 44.821 & 69.662 & 24.841 & 3.932 & 28.773 & 16.964 & 6.934 \\
\hline 72 & 83-MFT & MFT & 83 & 51744 & 87.907 & 312 & 28.9970 & 46.057 & 15 & 57.155 & 82.668 & 25.513 & 4.059 & 29.572 & 17.060 & 94.812 \\
\hline 73 & 84-SME & SME & 84 & 51826 & 91.644 & 518 & 28.4680 & 45.680 & 17 & 55.036 & 79.716 & 24.680 & 3.919 & 28.599 & 17.212 & 99.739 \\
\hline 74 & 84-SME & SME & 84 & 51826 & 89.302 & 524 & 27.6710 & 45.277 & 3 & 53.337 & 77.250 & 23.913 & 3.884 & 27.797 & 17.606 & 97.417 \\
\hline 75 & 84-SME & SME & 84 & 51826 & 88.663 & 519 & 28.3860 & 45.602 & 10 & 51.877 & 76.466 & 24.589 & 3.888 & 28.477 & 17.216 & 96.776 \\
\hline 76 & 84-SME & SME & 84 & 51826 & 90.58 & 564 & 28.6110 & 45.754 & 8 & 56.423 & 1.156 & 24.733 & 3.899 & 28.632 & 17.143 & 98.734 \\
\hline 77 & 84-SME & SME & 84 & 51826 & 91.929 & 562 & 28.6010 & 45.463 & 16 & 55.008 & 9.768 & 24.760 & 3.947 & 28.707 & 16.862 & 99.887 \\
\hline 78 & 84-SME & SME & 84 & 51826 & 88.965 & 521 & 28.0970 & 45.251 & 0 & 55.386 & 9.762 & 24.376 & 3.808 & 28.184 & 17.154 & 97.020 \\
\hline 79 & 84-MFT & MFT & 84 & 51923 & 89.025 & 570 & 28.5180 & 43.403 & 2 & 50.447 & 75.511 & 25.064 & 3.993 & 29.057 & 14.885 & 95.274 \\
\hline 80 & 84-MFT & MFT & 84 & 51923 & 91.951 & 605 & 27.8080 & 44.792 & 18 & 59.442 & 83.757 & 24.315 & 4.022 & 28.337 & 16.984 & 99.172 \\
\hline 81 & 84-MFT & MFT & 84 & 51923 & 88.555 & 992 & 28.5390 & 44.480 & 10 & 55.769 & 80.747 & 24.978 & 3.955 & 28.933 & 15.941 & 95.585 \\
\hline 82 & 84-MFT & MFT & 84 & 51923 & 91.637 & 568 & 27.6680 & 44.874 & 17 & 57.312 & .329 & 24.017 & 3.989 & 28.006 & 7.206 & 99.188 \\
\hline 83 & 84MFT & MFT & 84 & 51923 & 89.31 & 604 & 8.3130 & 45.366 & 7 & 58.684 & 3.339 & 24.655 & 3.975 & 28.630 & 17.053 & 96.841 \\
\hline 84 & 4-MFT & MFT & 84 & 51923 & 91.183 & 615 & 7.5910 & 44.964 & 5 & 52.390 & 6.461 & 24.071 & 3.937 & 28.008 & 7.373 & 98.727 \\
\hline 85 & 5-SME & SME & 85 & 51979 & 84.577 & 131 & 7.8090 & 45.778 & 18 & 59.433 & 3.407 & 23.974 & 3.977 & 27.951 & 7.969 & 13.426 \\
\hline 86 & 85-SME & SME & 85 & 51979 & 87.405 & 142 & 6740 & 45.567 & 2 & 50.436 & 4.305 & 23.869 & 3.906 & 27.775 & 7.893 & 96.096 \\
\hline 87 & 85-SME & SME & 85 & 51979 & 89.868 & 140 & .7360 & 45.435 & 10 & 55.817 & 0.699 & 23.882 & 3.988 & 27.870 & 17.699 & 98.463 \\
\hline 88 & 85-SME & SME & 85 & 51979 & 87.297 & 136 & 7.9340 & 45.689 & 1 & 57.359 & 1.439 & 24.080 & 3.978 & 28.058 & 17.755 & 5.996 \\
\hline 89 & 5-SME & SME & 85 & 51979 & 88.307 & 141 & 27.7260 & 45.201 & 12 & 51.006 & 4.967 & 23.961 & 3.888 & 27.849 & 7.475 & 96.848 \\
\hline 90 & 5-SME & SME & 85 & 51979 & 86.326 & 135 & 7.9920 & 45.638 & 7 & 58.698 & 2.864 & 4.166 & 3.947 & 8.113 & 7.646 & 4.904 \\
\hline 91 & 5-MFT & MFT & 85 & 52072 & 88.57 & 369 & 6940 & 45.178 & 16 & 54.402 & 3.298 & 23.896 & 3.896 & 27.792 & 7.484 & 96.860 \\
\hline 92 & 85-MFT & MFT & 85 & 52072 & 91.147 & 365 & 500 & 46.205 & 18 & 59.448 & 185 & 24.737 & 3.886 & 28.623 & 17.655 & 99.530 \\
\hline 93 & $85-M F T$ & MFT & 85 & 52072 & 89.316 & 368 & 3.5480 & 44.098 & 10 & 55.746 & 0.494 & 24.748 & 3.906 & 28.654 & 15.550 & 96.782 \\
\hline 94 & 5-MFT & MFT & 85 & 52072 & 89.036 & 362 & 19860 & 46.193 & 15 & 60.891 & .113 & 24.222 & 3.917 & 139 & 8.207 & 97.605 \\
\hline 95 & 5-MFT & MFT & 85 & 52072 & 91.982 & 381 & 3.0240 & 45.997 & 5 & 52.398 & 6.638 & 24.240 & 3.938 & 178 & 7.973 & 100.453 \\
\hline 96 & 85-MFT & MFT & 85 & 52072 & 91.633 & 374 & .1420 & 43.741 & 17 & 57.279 & .624 & 24.345 & 3.931 & 76 & 15.599 & 98.941 \\
\hline 97 & 86-SME & SME & 86 & 52147 & 89.039 & 681 & 3.0260 & 45.575 & 5 & 52.385 & .617 & 24.232 & 4.083 & 315 & 17.549 & 97.191 \\
\hline 98 & 6-SME & SME & 86 & 52147 & 91.957 & 803 & 27.6440 & 45.416 & 10 & 55.709 & 9.519 & 23.810 & 3.906 & .716 & 17.772 & 100.549 \\
\hline 99 & 6-SME & SME & 86 & $\begin{array}{l}6 \\
52147\end{array}$ & 88.562 & 804 & 3.3780 & 45.856 & 14 & 59.404 & 3.941 & 24.537 & 3.925 & 28.462 & 17.478 & 96.838 \\
\hline 100 & 86-SME & SME & 86 & 52147 & 91.63 & 808 & 28.0240 & 45.709 & 17 & 57.347 & 1.391 & 24.044 & 3.940 & 27.984 & 17.685 & 99.914 \\
\hline 101 & 6-SME & SME & 86 & 52147 & 89.306 & 811 & 890 & 46.086 & 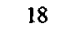 & 34 & 51 & 24.517 & 3.968 & & 87 & 97.982 \\
\hline 102 & 86-SME & SME & 86 & 52147 & 91.145 & 682 & 27.7180 & 45.654 & 19 & 60.681 & 1.500 & 23.819 & 3.998 & 27.817 & 17.936 & 99.456 \\
\hline 103 & 86-MFT & MFT & 86 & 52225 & 89.87 & 619 & 3.4520 & 45.978 & 2 & 50.429 & .191 & 24.762 & 3.760 & 28.522 & 7.526 & 98.329 \\
\hline 104 & 6-MFT & MFT & 86 & 52225 & 91.977 & 654 & 3560 & 46.007 & 5 & 52.381 & 5.946 & 24.565 & 3.887 & & 7.651 & 100.163 \\
\hline 105 & 86-MFT & MFT & 86 & 52225 & 88.582 & 657 & 28.5390 & 45.676 & 10 & 55.706 & 80.456 & 24.750 & 3.840 & 28.590 & 17.137 & 96.692 \\
\hline 106 & -MFT & FT & 86 & 52225 & 88.311 & 655 & 670 & 45.877 & 16 & 67 & 66 & 99 & 3.929 & 28 & 10 & 96.412 \\
\hline 107 & 86-MFT & MFT & 86 & 52225 & 89.306 & 623 & 3.5090 & 45.229 & 18 & 59.339 & 1.046 & 24.707 & 3.848 & .555 & 16.720 & 97.220 \\
\hline 108 & 6-MFT & MFT & 86 & 52225 & 91.153 & 622 & 88820 & 45.688 & 19 & 60.679 & 4.776 & 24.097 & 3.844 & 27.941 & 17.806 & 99.502 \\
\hline 109 & 7-SME & SME & 87 & 52269 & 91.634 & 986 & .9080 & 45.133 & 13 & 58.054 & 2.109 & 24.055 & 3.897 & 952 & 17.225 & 99.774 \\
\hline 110 & -SME & SME & 87 & 52269 & 87.409 & 988 & 1.9830 & 45.301 & & 58.226 & 2.367 & 24.141 & 3.887 & 28 & 17.318 & 95.599 \\
\hline 111 & -SME & SME & 87 & 52269 & 89.058 & 965 & 110 & 44.990 & 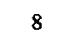 & 63.242 & 355 & 24.113 & 3.814 & 27 & 79 & 96.960 \\
\hline 112 & -SME & SME & 87 & 52269 & 88.3 & 977 & .0340 & 45.111 & 15 & 60.926 & 5.327 & 24.401 & 844 & 28.245 & 17.077 & 96.111 \\
\hline 113 & 7-SME & SME & 87 & 52269 & 86.333 & 972 & .0280 & 45.319 & 2 & 51.098 & 5.323 & 24.225 & 3.861 & 28.086 & 17.291 & 94.495 \\
\hline 114 & SME & SME & 87 & 52269 & 87.894 & 966 & .9610 & 45.064 & 1 & 57.521 & 1.719 & 24.198 & 3.814 & & 103 & 95.786 \\
\hline 115 & MFT & MFT & 87 & 52406 & 91.979 & 411 & .6590 & 45.153 & 11 & & 74 & 23.858 & 3.753 & & 17.494 & 99.951 \\
\hline 116 & -MFT & MFT & 87 & 52406 & 89.411 & 469 & .4400 & 44.368 & 10 & 53.919 & 412 & 23.493 & 3.934 & 27.427 & 16.928 & 97.157 \\
\hline 117 & -MFT & MFT & 7 & 52406 & 89.849 & $106(601)$ & 1.9990 & 43.443 & 5 & 47.613 & 301 & 24.188 & 3.925 & 13 & 15.444 & 96.903 \\
\hline 118 & -MFT & MFT & 87 & 52406 & 87.877 & 586 & .9540 & 43.518 & 6 & 53.963 & 3.097 & 24.134 & 3.924 & 8.058 & 15.564 & 95.059 \\
\hline 119 & -MFT & MFT & 87 & 52406 & 88.562 & 600 & 27.7900 & 43.163 & 15 & 59.981 & 4.081 & 24.100 & 3.887 & 7.987 & 15.373 & 95.518 \\
\hline 120 & -MFT & MFT & 87 & 52406 & 91.677 & 413 & 27.7490 & 43.887 & 12 & 53.650 & 7.567 & 23.917 & 3.986 & 27.903 & 16.138 & 98.845 \\
\hline 121 & SME & $S M E$ & 88 & 52502 & 91.659 & 131 & 27.8150 & 45.711 & 8 & 57.602 & 1.235 & 23.633 & 3.999 & & 17.896 & 100.171 \\
\hline 122 & SME & ME & 88 & 52502 & 92.151 & 128 & 9010 & 45.493 & 1 & 59.216 & .024 & 23.808 & 4.047 & & 17.592 & 100.350 \\
\hline 123 & SME & SME & 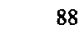 & 52502 & 89.909 & 12 & 8740 & 45.690 & 0 & 53.200 & 927 & 23.727 & 4.064 & 7.791 & 17.816 & 98.351 \\
\hline 124 & 3-SME & SME & 88 & 52502 & 89.317 & 129 & 28.0460 & 45.725 & 7 & 59.944 & 83.701 & 23.757 & 4.137 & 27.894 & 17.679 & 97.682 \\
\hline 125 & 8-SME & SME & 88 & 52502 & 89.027 & 130 & 27.8480 & 45.444 & 3 & 60.399 & 84.053 & 23.654 & 4.048 & 27.702 & 17.596 & 97.058 \\
\hline 126 & -SME & SME & 88 & 52502 & 88.339 & 127 & 8190 & 45.637 & 22 & 2.283 & 5.030 & 23.747 & 4.002 & & 17.818 & 96.765 \\
\hline 127 & -MFT & MFT & 8 & 52561 & 84.582 & 20 & 28.1160 & 43.978 & 3 & .082 & 4.214 & 24.132 & 3.875 & 28.007 & 15.862 & 91.742 \\
\hline 128 & -MFT & MFT & $\infty$ & 52561 & 90.036 & 20 & 7.8860 & 44.730 & 21 & 55.796 & 8.521 & 22.725 & 3.884 & 26.609 & 16.844 & 97.952 \\
\hline 129 & 88-MFT & MFT & 88 & 52561 & 87.568 & 401 & 27.8590 & 45.835 & 6 & 53.819 & 77.822 & 24.003 & 3.889 & 27.892 & 17.976 & 95.831 \\
\hline 130 & MFT & MFT & 88 & 52561 & 92.19 & 415 & 27.8490 & 44.959 & 11 & 51.760 & 86.308 & 34.548 & 3.916 & 38.464 & 17.110 & 100.115 \\
\hline 131 & 3-MFT & MFT & 88 & 52561 & 88.394 & 416 & 27.8470 & 45.611 & 4 & 54.579 & 75.699 & 21.120 & 3.869 & 24.989 & 17.764 & 96.505 \\
\hline 132 & 3-MFT & MFT & 88 & 52561 & 89.348 & 417 & 27.6290 & 45.312 & 9 & 62.577 & 79.534 & 16.957 & 3.856 & 20.813 & 17.683 & .97 .642 \\
\hline 133 & 89-SME & SME & 89 & 52637 & 91.633 & 20 & 7.7440 & 46.877 & 3 & 59.977 & 83.997 & 24.020 & 3.894 & 27.914 & 19.133 & 99.66 \\
\hline & & & & & & & & & & & & & & & & \\
\hline
\end{tabular}


Table A.1: Macro-Batch 1A Sample Weights

\begin{tabular}{|c|c|c|c|c|c|c|c|c|c|c|c|c|c|c|c|c|}
\hline & & & & & Empty & & Empty & & & & Dried & & & Actual & Actual & Total \\
\hline $\begin{array}{c}\text { Print } \\
\text { Row ID }\end{array}$ & $\begin{array}{l}\text { Batcb- } \\
\text { Vessel }\end{array}$ & Vessel & Batch & LIMS \# & $\begin{array}{l}\text { Platinum } \\
\text { wt (g) }\end{array}$ & $\begin{array}{l}\text { Vial } \\
\text { ID }\end{array}$ & $\begin{array}{c}\text { Vial + Cap } \\
\text { wt (g) }\end{array}$ & $\begin{array}{l}\text { Filled } \\
\text { wt }(g)\end{array}$ & $\mathrm{Zr}$ ID & $\begin{array}{c}\text { Empty } \\
\text { Zr wt (g) }\end{array}$ & $\begin{array}{c}\text { Vial }+\mathrm{Zr} \\
\text { wt (g) }\end{array}$ & $\begin{array}{c}\text { Calc } \\
\text { wt (g) }\end{array}$ & $\begin{array}{l}\text { Cap } \\
\text { wt (g) }\end{array}$ & $\begin{array}{c}\text { Vial + Cap } \\
\text { wt (g) }\end{array}$ & $\begin{array}{l}\text { Sample } \\
\text { wt (g) }\end{array}$ & $\begin{array}{l}\text { Dried } \\
\text { wt (g) }\end{array}$ \\
\hline 135 & 89-SME & SME & 89 & 52637 & 84.572 & 121 & 27.7530 & 45.266 & 20 & 54.725 & 78.833 & 24.108 & 3.842 & 27.950 & 17.513 & 92.670 \\
\hline 136 & 89-SME & SME & 89 & 52637 & 89.895 & 205 & 27.9990 & 46.068 & 32 & 53.935 & 78.157 & 24.222 & 4.038 & 28.260 & 18.069 & 98.241 \\
\hline 137 & 89-SME & SME & 89 & 52637 & 89.396 & 211 & 28.0540 & 45.102 & 1 & 51.482 & 75.919 & 24.437 & 4.076 & 28.513 & 17.048 & 94.652 \\
\hline 138 & 89-SME & SME & 89 & 52637 & 87.57 & 962 & 27.8390 & 45.486 & 5 & 58.889 & 82.996 & 24.107 & 3.900 & 28.007 & 17.647 & 95.829 \\
\hline 139 & 89-MFT & MFT & 89 & 52752 & 84.568 & 309 & 27.5570 & 44.329 & 4 & 54.533 & 78.338 & 23.805 & 3.866 & 27.671 & 16.772 & 92.093 \\
\hline 140 & 89-MFT & MFT & 89 & 52752 & 89.862 & 314 & 27.6320 & 44.889 & 6 & 53.852 & 77.631 & 23.779 & 3.942 & 27.721 & 17.257 & 97.413 \\
\hline 141 & 89-MFT & MFT & 89 & 52752 & 89.031 & 307 & 27.5810 & 45.247 & 9 & 58.925 & 82.742 & 23.817 & 3.865 & 27.682 & 17.666 & 96.959 \\
\hline 142 & 89-MFT & MFT & 89 & 52752 & 88.552 & 308 & 27.5300 & $45.183^{\circ}$ & 10 & 53.588 & 77.333 & 23.745 & 3.856 & 27.601 & 17.653 & 96.447 \\
\hline 143 & 89-MFT & MFT & 89 & 52752 & 88.296 & 316 & 27.6020 & 45.214 & 20 & 54.764 & 78.534 & 23.770 & 3.919 & $27.689^{\circ}$ & 17.612 & 96.072 \\
\hline 144 & 89-MFT & MFT & 89 & 52752 & 89.312 & 312 & 28.1010 & 44.825 & 0 & 59.731 & 84.068 & 24.337 & 3.878 & 28.215 & 16.724 & 96.528 \\
\hline 145 & 90-SME & SME & 90 & 52826 & 89.86 & 421 & 27.5020 & 45.295 & 0 & 53.497 & 77.937 & 24.440 & 3.890 & 28.330 & 17.793 & 96.587 \\
\hline 146 & 90-SME & SME & 90 & 52826 & 87.404 & 420 & 28.0440 & 45.325 & A & 59.400 & 84.143 & 24.743 & 3.876 & 28.619 & 17.281 & 94.421 \\
\hline 147 & 90-SME & SME & 90 & 52826 & 89.315 & 425 & 27.7540 & 45.162 & 6 & 53.596 & 78.635 & 25.039 & 3.873 & 28.912 & 17.408 & 95.347 \\
\hline 148 & 90-SME & SME & 90 & 52826 & 84.576 & 424 & 27.6190 & 45.150 & 0 & 45.327 & 69.211 & 23.884 & 3.974 & 27.858 & 17.531 & 92.208 \\
\hline 149 & 90-SME & SME & 90 & 52826 & 88.683 & 407 & 28.1460 & 45.540 & 1 & 58.749 & 83.530 & 24.781 & 4.095 & 28.876 & 394 & 95.643 \\
\hline 150 & 90-SME & SME & 90 & 52826 & 87.27 & 409 & 27.8950 & 45.351 & 2 & 54.598 & 79.117 & 24.519 & 4.189 & 28.708 & 17.456 & 93.303 \\
\hline 151 & 90-MFT & MFT & 90 & 53066 & 89.314 & 391 & 27.9470 & 45.524 & 9 & 51.289 & 75.430 & 24.141 & 3.930 & 28.071 & 17.577 & 97.294 \\
\hline 152 & 90-MFT & MFT & 90 & 53066 & 87.403 & 398 & 27.8660 & 45.538 & 23 & 55.018 & 79.105 & 24.087 & 3.939 & 28.026 & 17.672 & 95.193 \\
\hline 153 & $90-\mathrm{MFT}$ & MFT & 90 & 53066 & 88.359 & 409 & 27.2350 & 43.830 & 20 & 54.389 & 77.810 & 23.421 & 3.978 & 27.399 & 16.595 & 95.657 \\
\hline 154 & 90 -MFT & MFT & 90 & 53066 & 88.555 & 408 & 27.9320 & 45.427 & 21 & 55.646 & 79.811 & 24.165 & 3.901 & 28.066 & 17.495 & 96.353 \\
\hline 155 & 90-MFT & MFT & 90 & 53066 & 91.146 & 405 & 27.9340 & 45.165 & 5 & 47.228 & 71.422 & 24.194 & 3.891 & 28.085 & 17.231 & 98.777 \\
\hline 156 & 90-MFT & MFT & 90 & 53066 & 90.577 & 407 & 27.8680 & 45.524 & 0 & 53.858 & 77.979 & 24.121 & 3.903 & 28.024 & 17.656 & 98.437 \\
\hline 157 & 92-SME & SME & 92 & 53161 & 84.576 & 516 & 27.8660 & 44.340 & 1 & 53.838 & 78.008 & 24.170 & 3.907 & 28.077 & 16.474 & 91.375 \\
\hline 158 & 92-SME & SME & 92 & 53161 & 92.162 & 520 & 27.9180 & 44.406 & 0 & 58.594 & 82.866 & 24.272 & 3.985 & 28.257 & 16.488 & 98.766 \\
\hline 159 & 92-SME & SME & 92 & 53161 & 88.96 & 507 & 27.3300 & 43.847 & 20 & 54.321 & 78.149 & 23.828 & 3.777 & 27.605 & 16.517 & 95.968 \\
\hline 160 & 92-SME & SME & 92 & 53161 & 89.74 & 504 & 27.7280 & 44.449 & 10 & 53.202 & 77.459 & 24.257 & 3.803 & 28.060 & 16.721 & 96.752 \\
\hline 161 & 92-SME & SME & 92 & 53161 & 92.034 & 521 & 27.3680 & 44.316 & 0 & 51.279 & 75.044 & 23.765 & 3.885 & 27.650 & 16.948 & 99.181 \\
\hline 162 & 92-SME & SME & 92 & 53161 & 88.549 & 523 & 27.4440 & 44.284 & 2 & 55.601 & 79.431 & 23.830 & 3.953 & 27.783 & 16.840 & 95.613 \\
\hline 163 & 92-MFT & MFT & 92 & 53235 & 87.844 & 644 & 25.4280 & 42.744 & 30 & 53.194 & 76.881 & 23.687 & 1.914 & 25.601 & 17.316 & 94.532 \\
\hline 164 & 92-MFT & MFT & 92 & 53235 & 96.184 & 646 & 25.3980 & 40.877 & 13 & 58.609 & 82.218 & 23.609 & 1.818 & 25.427 & 15.479 & 102.457 \\
\hline 165 & 92-MFT & MFT & 92 & 53235 & 89.074 & 651 & 25.8280 & 42.836 & 20 & 54.357 & 78.475 & 24.118 & 1.831 & 25.949 & 17.008 & 96.249 \\
\hline 166 & 92-MFT & MFT & 92 & 53235 & 89.244 & 648 & 25.9090 & 42.908 & 73 & 59.350 & 83.417 & 24.067 & 1.953 & 26.020 & 16.999 & 95.711 \\
\hline 167 & 92-MFT & MFT & 92 & 53235 & 89.471 & 653 & 25.3580 & 43.289 & 21 & 55.712 & 79.266 & 23.554 & 1.847 & 25.401 & 17.931 & 96.364 \\
\hline 168 & 92-MFT & MFT & 92 & 53235 & 89.625 & 645 & 25.9350 & 42.978 & 1 & 53.916 & 77.920 & 24.004 & 1.962 & 25.966 & 17.043 & 95.646 \\
\hline
\end{tabular}

Shaded entries were deemed as unrepresentative by DWPF Engineering and were not included in these analyses. 


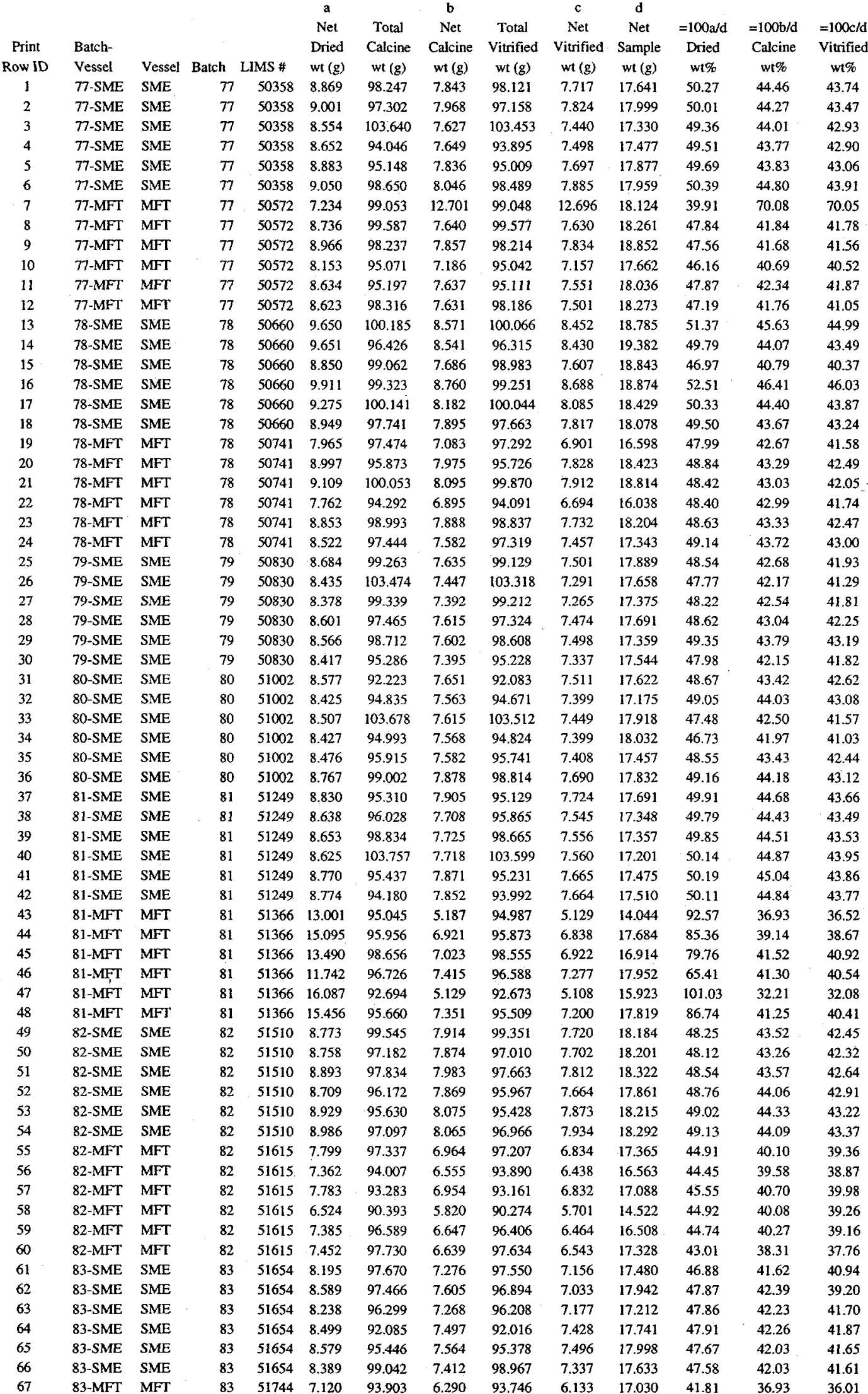

Shaded entries were deemed as unrepresentative by DWPF Engineering and were not included in these analyses. 


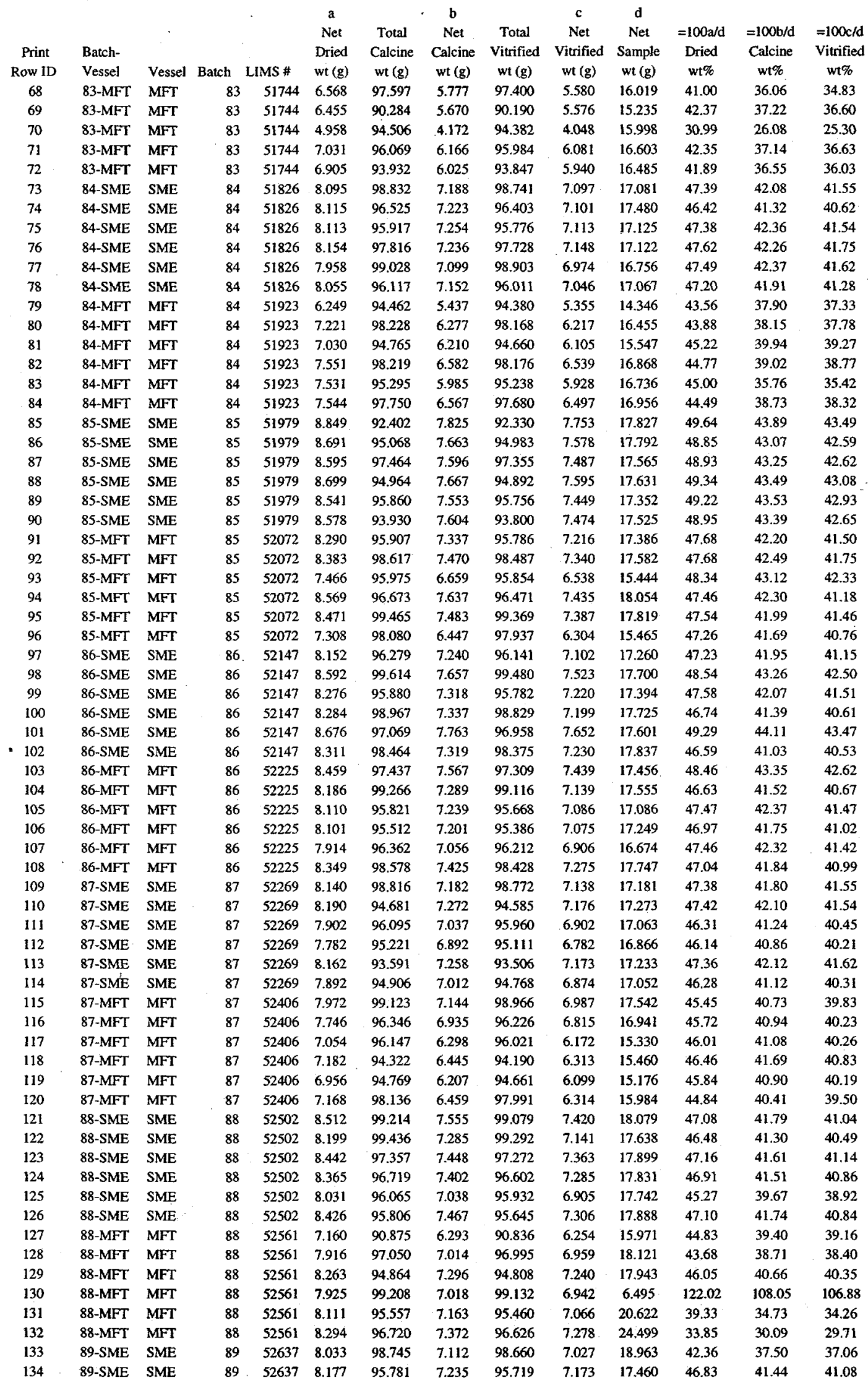

Shaded entries were deemed as unrepresentative by DWPF Engineering and were not included in these analyses. 


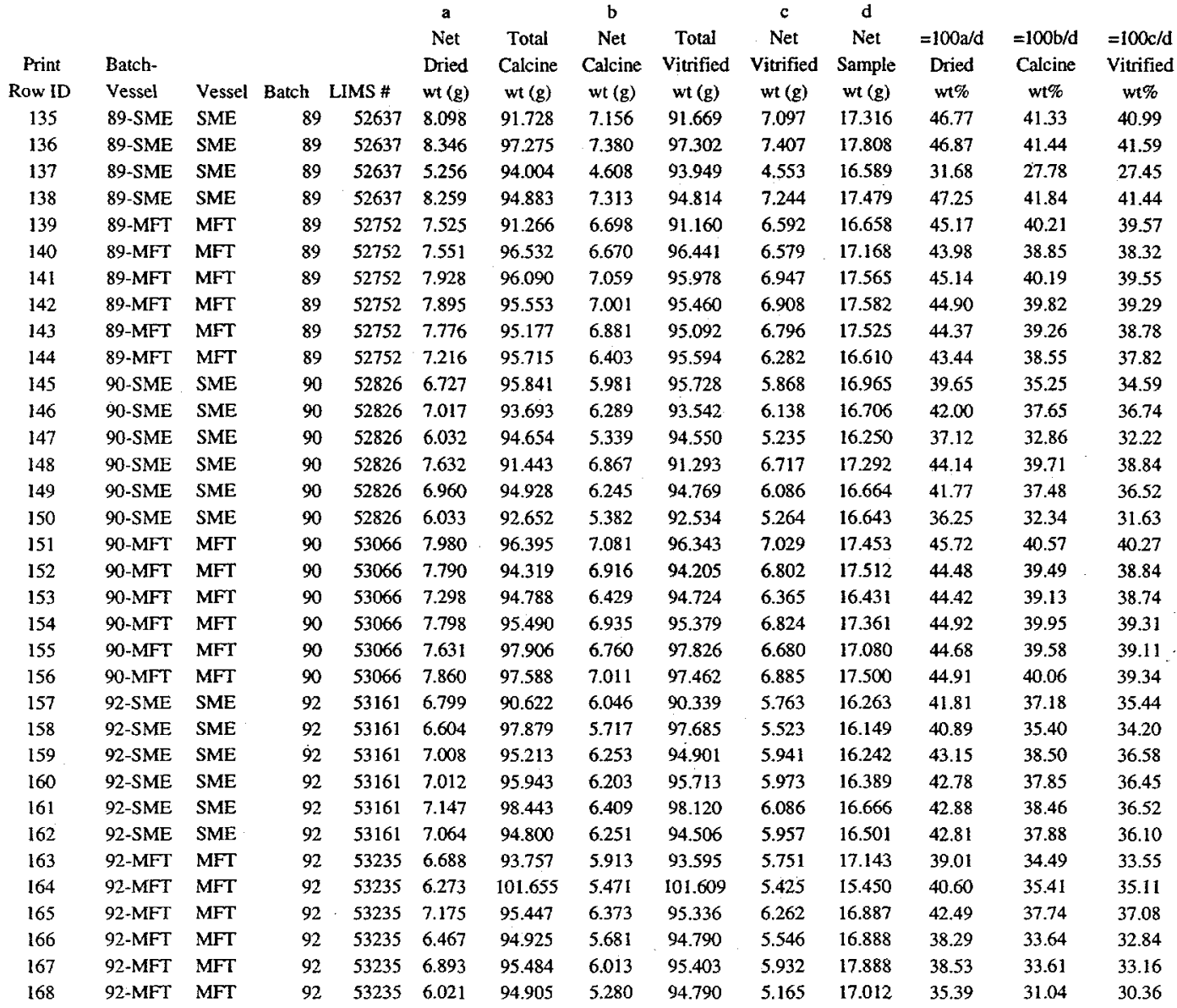


Dried wt \% By Batch-Vessel

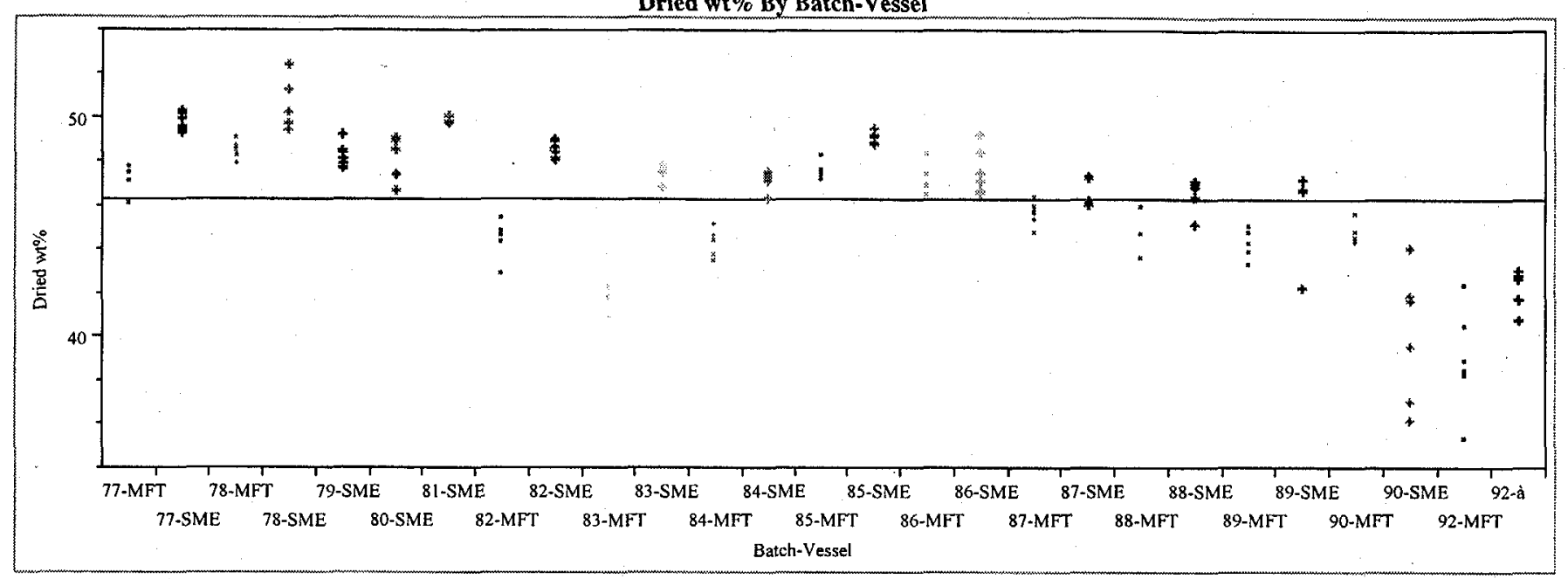

Calcine wt\% By Batch-Vesse

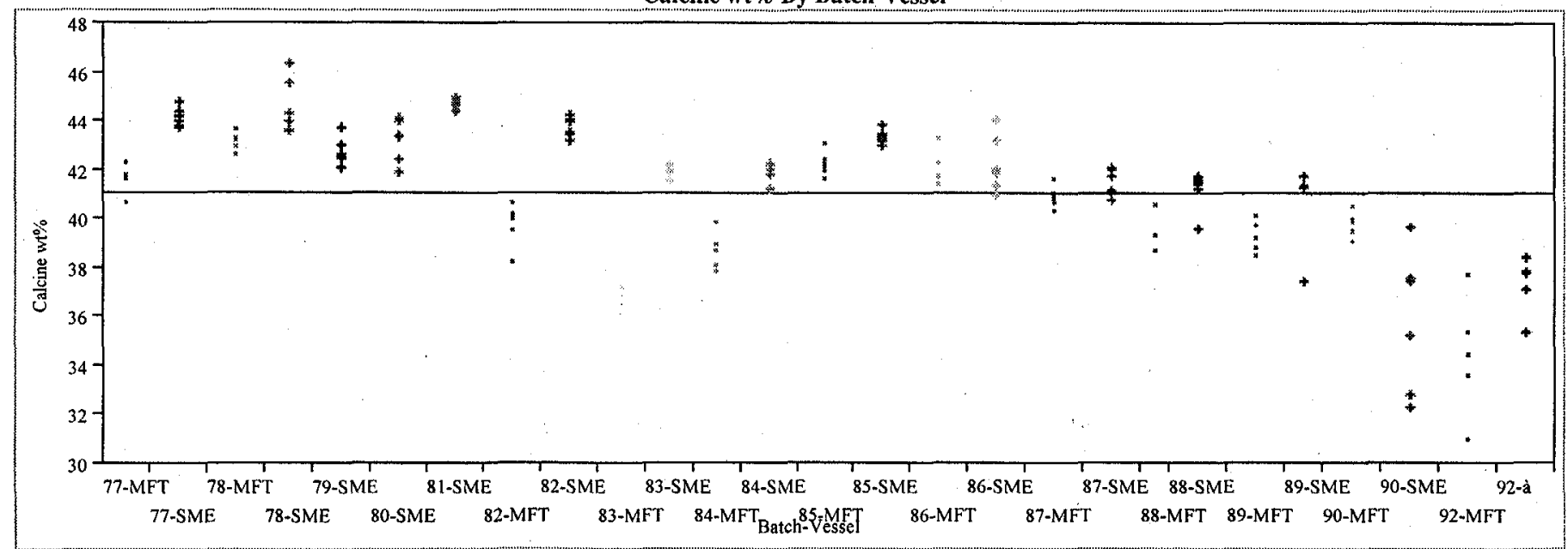


Vitrified wt \% By Batch-Vessel

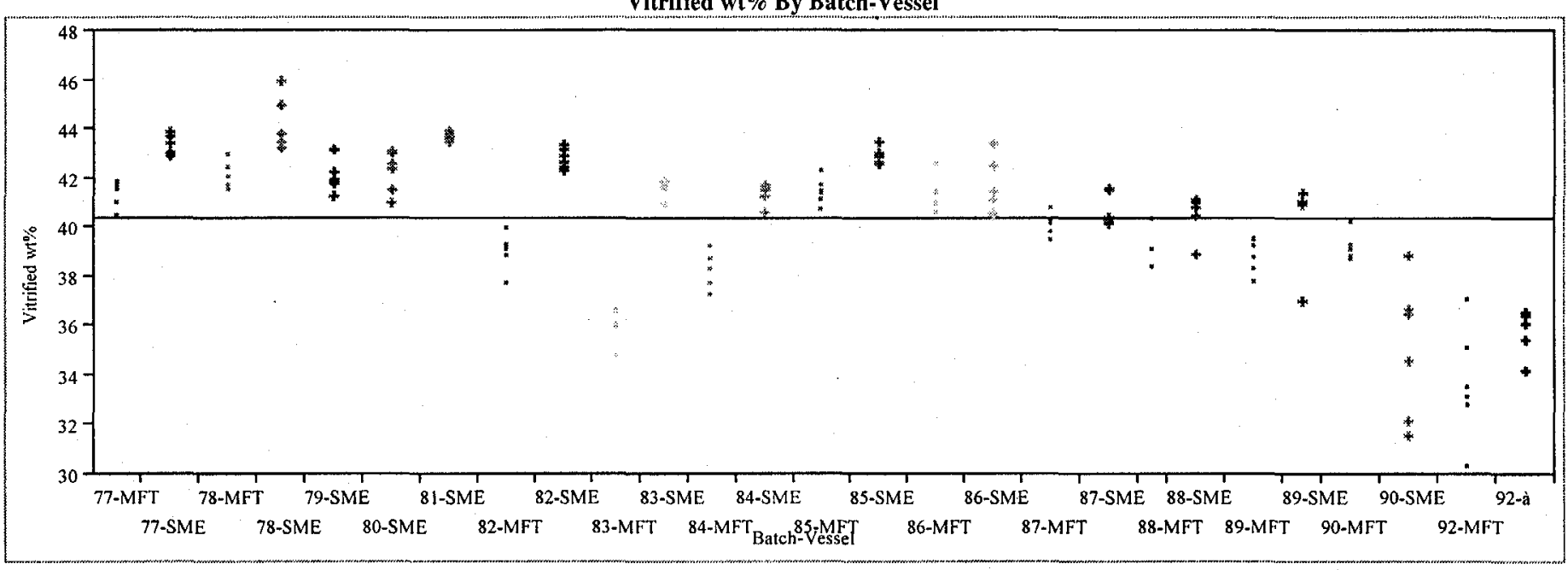




\section{Vessel=SME}
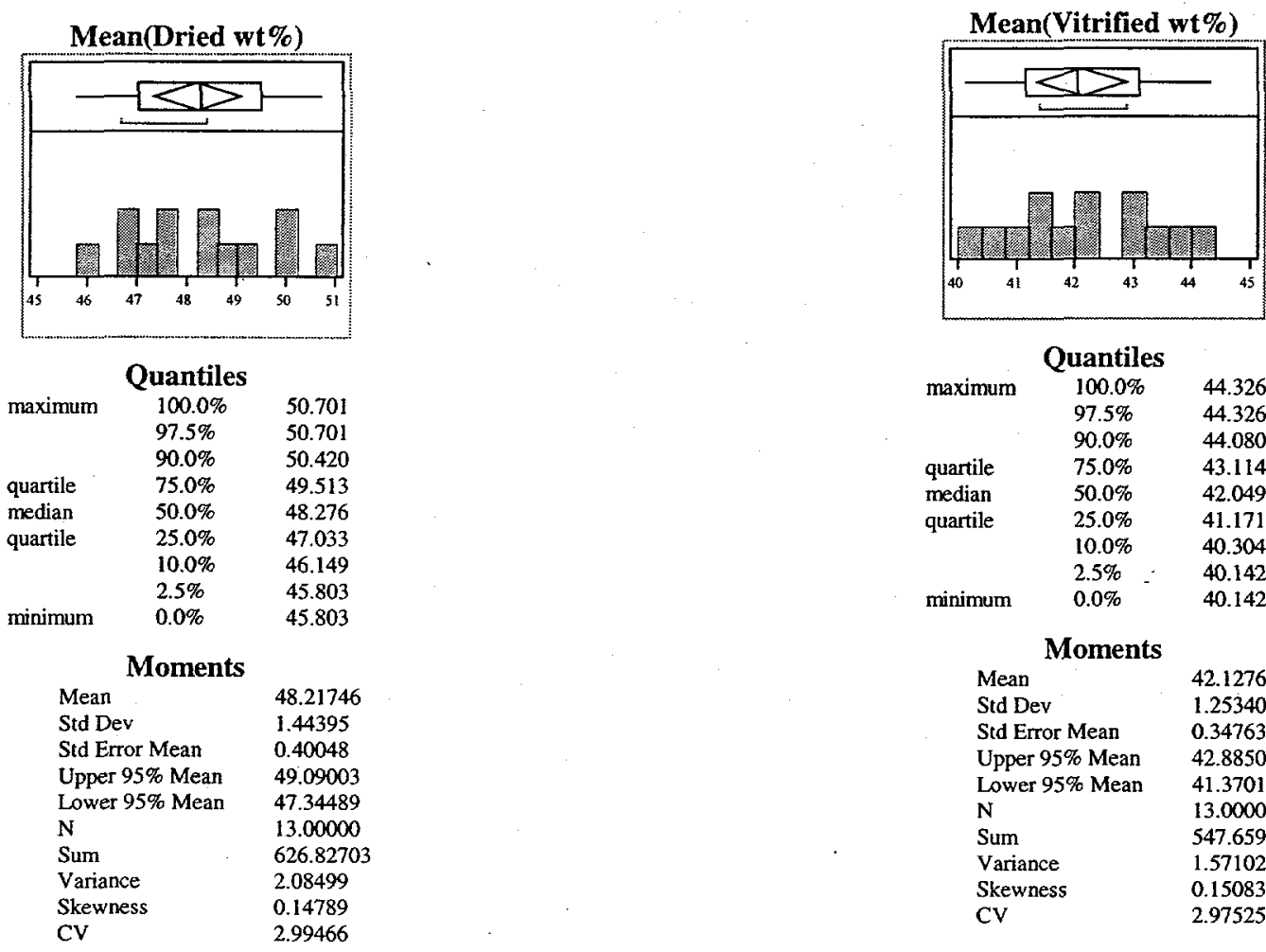

$\begin{array}{lcc} & \text { Quantiles } \\ \text { maximum } & 100.0 \% & 44.326 \\ & 97.5 \% & 44.326 \\ & 90.0 \% & 44.080 \\ \text { quartile } & 75.0 \% & 43.114 \\ \text { median } & 50.0 \% & 42.049 \\ \text { quartile } & 25.0 \% & 41.171 \\ & 10.0 \% & 40.304 \\ & 2.5 \% & 40.142 \\ \text { minimum } & 0.0 \% & 40.142\end{array}$

\begin{tabular}{ll}
\multicolumn{1}{c}{ Moments } \\
Mean & 42.12762 \\
Std Dev & 1.25340 \\
Std Error Mean & 0.34763 \\
Upper 95\% Mean & 42.88504 \\
Lower 95\% Mean & 41.37019 \\
N & 13.00000 \\
Sum & 547.65900 \\
Variance & 1.57102 \\
Skewness & 0.15083 \\
CV & 2.97525
\end{tabular}

Mean(Calcine wt\%)

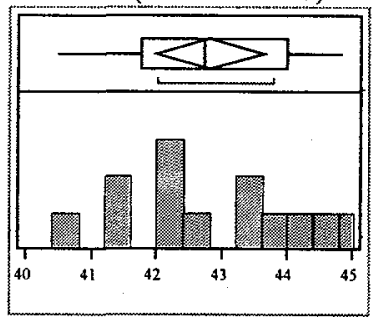

Quantiles

\begin{tabular}{lll} 
maximum & $100.0 \%$ & 44.835 \\
& $97.5 \%$ & 44.835 \\
& $90.0 \%$ & 44.793 \\
quartile & $75.0 \%$ & 43.998 \\
median & $50.0 \%$ & 42.731 \\
quartile & $25.0 \%$ & 41.788 \\
& $10.0 \%$ & 40.824 \\
& $2.5 \%$ & 40.527 \\
minimum $\quad 0.0 \%$ & 40.527 \\
\multicolumn{1}{c}{ Moments } \\
Mean & \\
Std Dev & 42.82350 \\
Std Error Mean & 1.35107 \\
Upper 95\% Mean & 0.37472 \\
Lower 95\% Mean & 43.63995 \\
N & 42.00706 \\
Sum & 13.00000 \\
Variance & 556.70554 \\
Skewness & 1.82539 \\
CV & -0.00781 \\
\end{tabular}


Appendix: Tables and Exhibits

Exhibit A2: Descriptive Statistics for the Sample Weights by Vessel

\section{Vessel $=$ MFT}
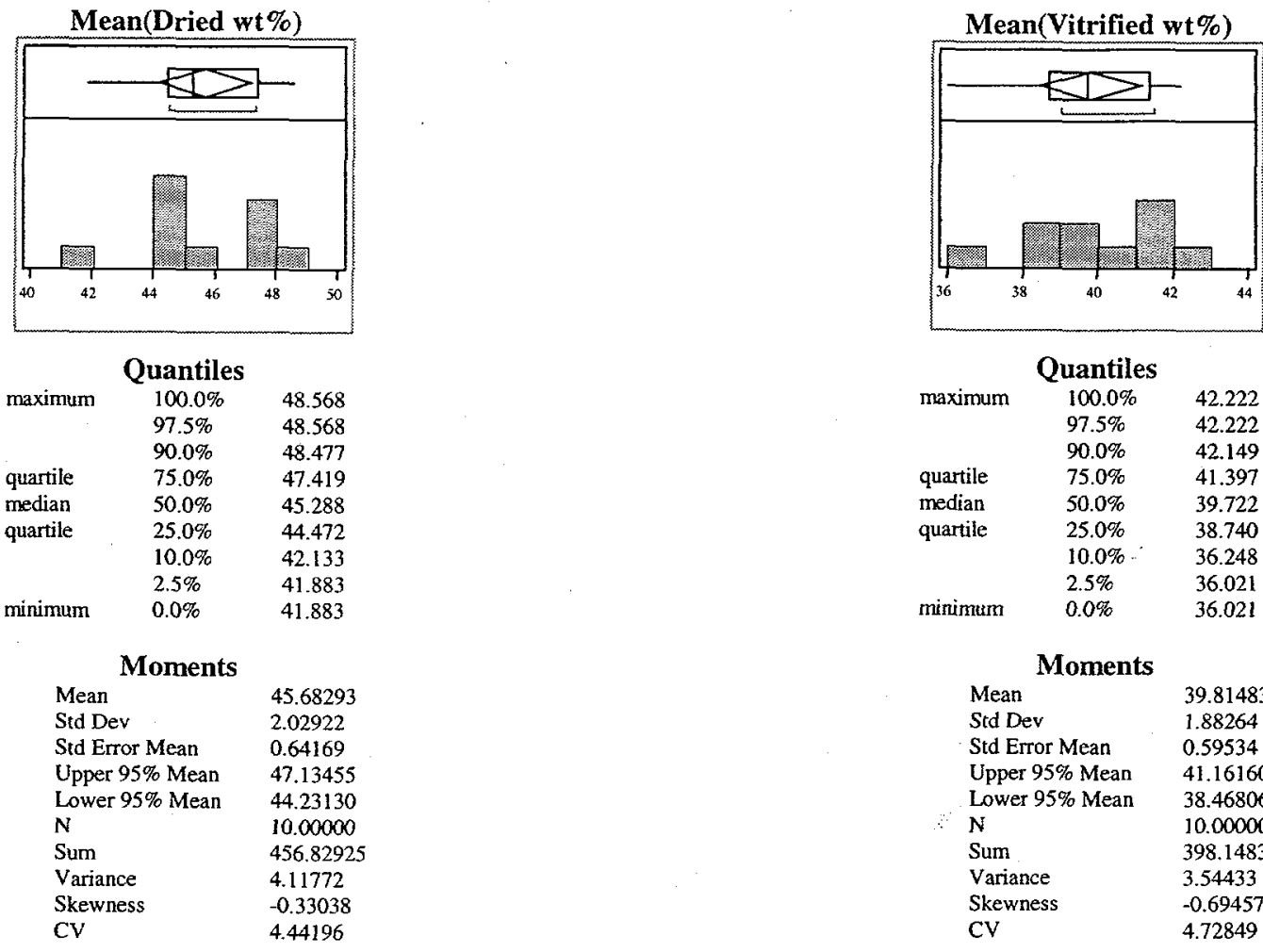

\begin{tabular}{ll}
\multicolumn{1}{c}{ Moments } \\
Mean & 39.81483 \\
Std Dev & 1.88264 \\
Std Error Mean & 0.59534 \\
Upper 95\% Mean & 41.16160 \\
Lower 95\% Mean & 38.46806 \\
N & 10.00000 \\
Sum & 398.14830 \\
Variance & 3.54433 \\
Skewness & -0.69457 \\
CV & 4.72849
\end{tabular}

Mean(Calcine wt\%)

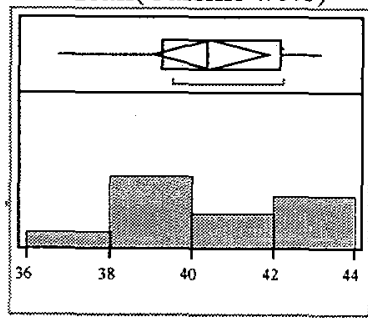

\begin{tabular}{lcc}
\multicolumn{3}{c}{ Quantiles } \\
maximum & $100.0 \%$ & 43.172 \\
& $97.5 \%$ & 43.172 \\
& $90.0 \%$ & 43.084 \\
quartile & $75.0 \%$ & 42.217 \\
median & $50.0 \%$ & 40.398 \\
quartile & $25.0 \%$ & 39.297 \\
& $10.0 \%$ & 36.977 \\
& $2.5 \%$ & 36.780 \\
minimum $\quad 0.0 \%$ & 36.780 \\
\multicolumn{3}{c}{ Moments } \\
Mean & \\
Std Dev & 40.47147 \\
Std Error Mean & 1.94326 \\
Upper 95\% Mean & 0.61451 \\
Lower 95\% Mean & 41.86161 \\
N & 39.08133 \\
Sum & 10.00000 \\
Variance & 404.71471 \\
Skewness & 3.77627 \\
CV & -0.46697 \\
& 4.80156
\end{tabular}




\begin{tabular}{|c|c|c|}
\hline & rrelations & \\
\hline $\begin{array}{l}\text { Variable Dried wt } \% \\
\text { Dried wt } \% 1.0000\end{array}$ & $\begin{array}{c}\text { Calcine wt\% } \\
0.9938\end{array}$ & $\begin{array}{l}\text { Vitrified wt \% } \\
0.9945\end{array}$ \\
\hline wt\% & 0.9938 & 1.0000 \\
\hline $\mathrm{wt} \%$ & 0.9945 & 0.9941 \\
\hline
\end{tabular}

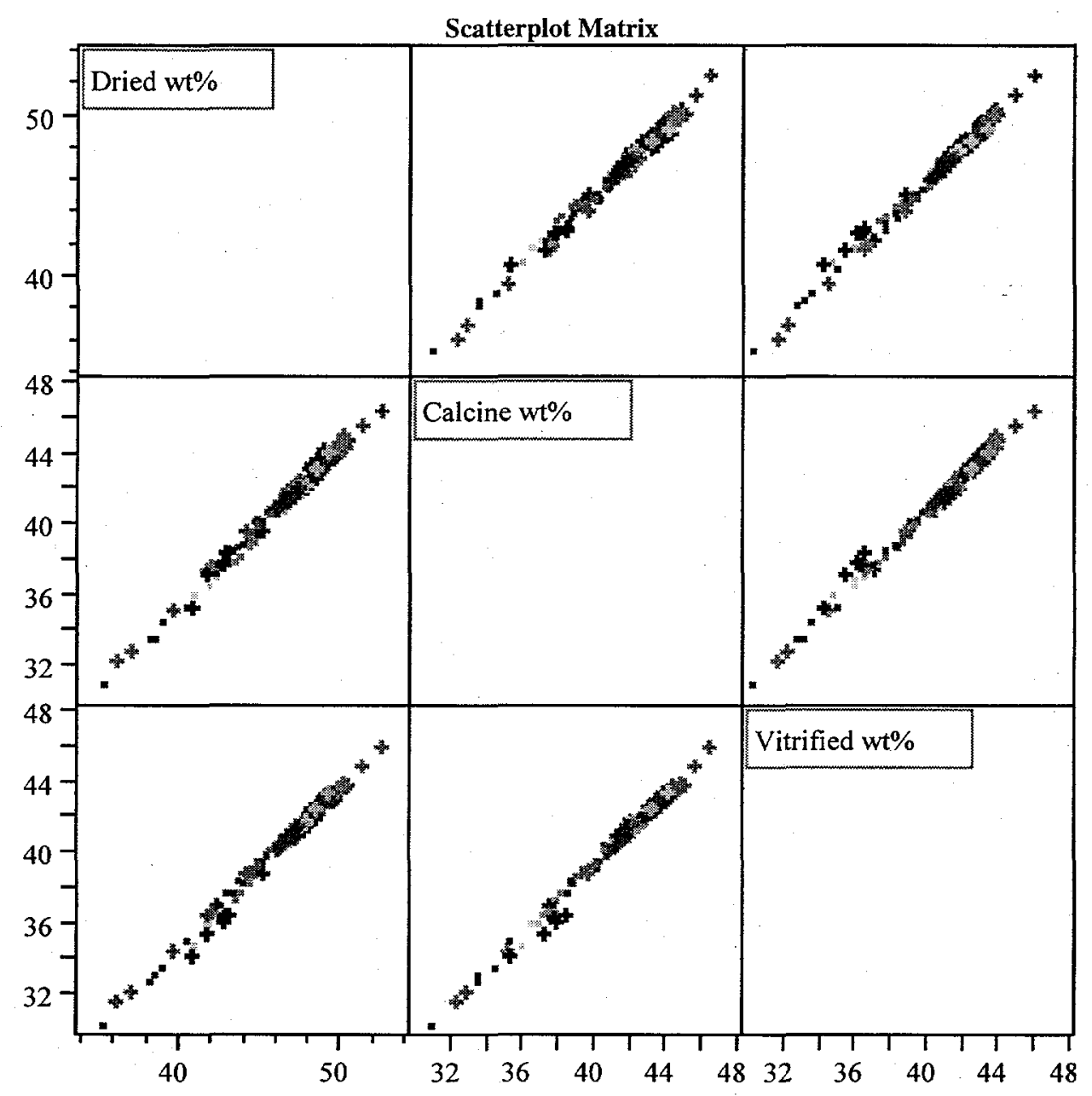


Appendix: Tables and Exhibits

Page A12

Exhibit A.3: Correlations and Scatter Plots for Sample Weight Percents

(Continued)

This page intentionally left blank. 
Vit Factor By Batch

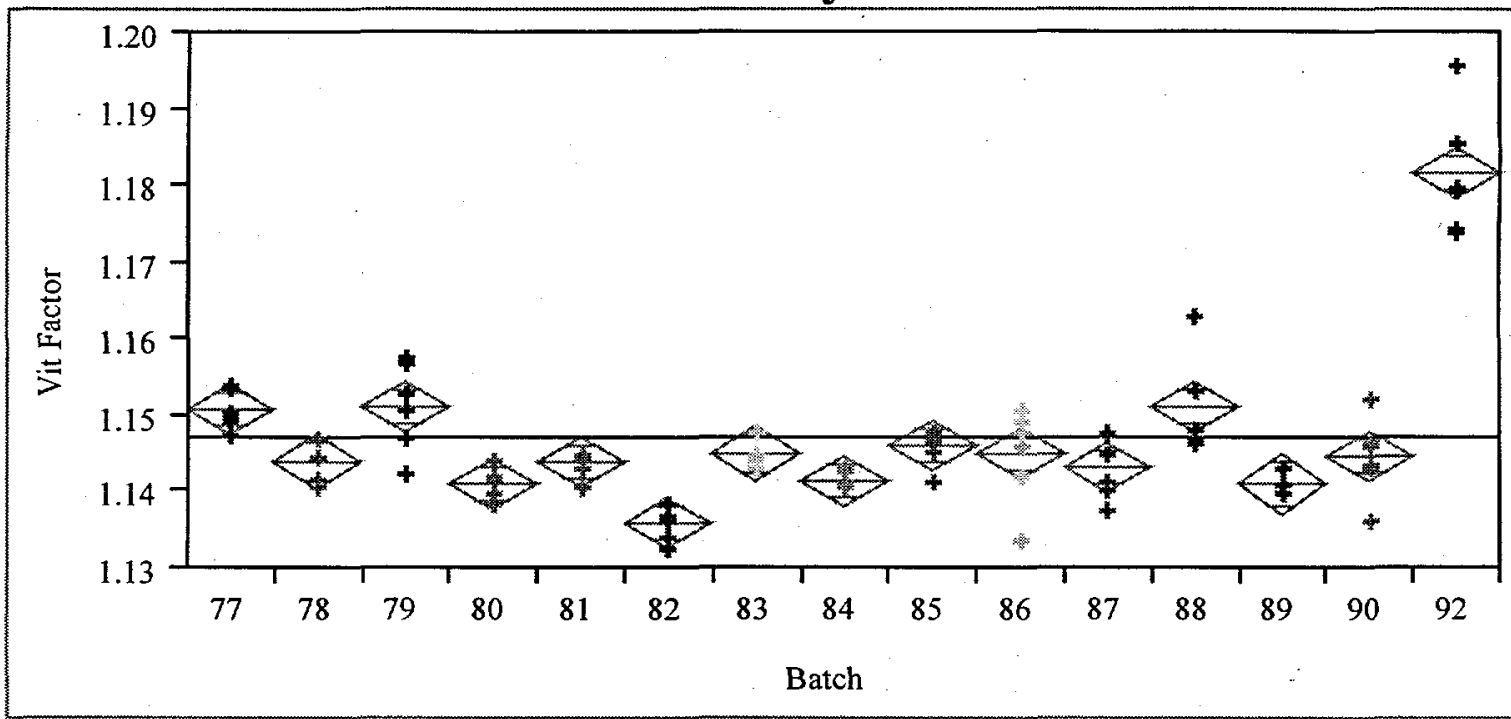

\begin{tabular}{lr}
\multicolumn{2}{c}{ Oneway Anova } \\
Summary of Fit \\
RSquare & 0.874001 \\
RSquare Adj & 0.849156 \\
Root Mean Square Error & 0.004279 \\
Mean of Response & 1.147263 \\
Observations (or Sum Wgts) & 86
\end{tabular}

$\begin{array}{lr}\text { Source } & \text { DF } \\ \text { Model } & 14 \\ \text { Error } & 71 \\ \text { C Total } & 85\end{array}$

Analysis of Variance

$\begin{array}{rrr}\text { Sum of Squares } & \text { Mean Square } & \text { F Ratio } \\ 0.00901565 & 0.000644 & 35.1783 \\ 0.00129973 & 0.000018 & \text { Prob }>\text { F } \\ 0.01031538 & 0.000121 & <.0001\end{array}$

Means for Oneway Anova

$\begin{array}{lrrr}\text { Level } & \text { Number } & \text { Mean } & \text { Std Error } \\ 77 & 6 & 1.15086 & 0.00175 \\ 78 & 5 & 1.14387 & 0.00191 \\ 79 & 6 & 1.15137 & 0.00175 \\ 80 & 6 & 1.14096 & 0.00175 \\ 81 & 6 & 1.14385 & 0.00175 \\ 82 & 6 & 1.13583 & 0.00175 \\ 83 & 5 & 1.14501 & 0.00191 \\ 84 & 6 & 1.14151 & 0.00175 \\ 85 & 6 & 1.14598 & 0.00175 \\ 86 & 6 & 1.14504 & 0.00175 \\ 87 & 6 & 1.14333 & 0.00175 \\ 88 & 6 & 1.15108 & 0.00175 \\ 89 & 4 & 1.14107 & 0.00214 \\ 90 & 6 & 1.14463 & 0.00175 \\ 92 & 6 & 1.18153 & 0.00175\end{array}$

Std Error uses a pooled estimate of error variance 


$\begin{array}{lr}\text { Level } & \text { Count } \\ 77 & 6 \\ 78 & 5 \\ 79 & 6 \\ 80 & 6 \\ 81 & 6 \\ 82 & 6 \\ 83 & 5 \\ 84 & 6 \\ 85 & 6 \\ 86 & 6 \\ 87 & 6 \\ 88 & 6 \\ 89 & 4 \\ 90 & 6 \\ 92 & 6\end{array}$

\section{Tests that the Variances are Equal}

Std Dev
0.0025816
0.0025968
0.0058606
0.0021235
0.0016227
0.0021014
0.0017043
0.0011767
0.0024456
0.0062630
0.0041144
0.0063420
0.0014719
0.0052338
0.0081992

MeanAbsDif to Mean

0.0020880

0.0020917

0.0045653

0.0017448

0.0012128

0.0016432

0.0011992

0.0009947

0.0017472

0.0047222

0.0034785

0.0047351

0.0010444

0.0036137

0.0061630

DF Num

F Ratio
1.3743
1.4780
2.8455
3.0588

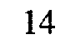

14

14

14
MeanAbsDif to Median

0.0019446

0.0019086

0.0045653

0.0017448

0.0011092

0.0014680

0.0011504

0.0008575

0.0015424

0.0043163

0.0034785

0.0037911

0.0010306

0.0036137

0.0055738
Test

OBrien[.5]

Brown-Forsythe

Levene

Bartlett
DF Den

71

71

71
Prob $>$ F

0.1887

0.1421

0.0020

$<.0001$

Warning: Small sample sizes. Use Caution.

Welch Anova testing Means Equal, allowing Std's Not Equal

$\begin{array}{lrrr}\text { F Ratio } & \text { DF Num } & \text { DF Den } & \text { Prob }>\text { F } \\ 17.3060 & 14 & 26.5 & <.0001\end{array}$




\section{DISTRIBUTION:}

\section{SRTC}

N. E. Bibler, 773-A

K. G. Brown, 704-1T

P. F. Cloessner, 773-A

C. J. Coleman, 773-A

D. A. Crowley, 773-43A

T. B. Edwards, 773-42A

T. L. Fellinger, 773-A

J. R. Harbour, 773-43A

S. P. Harris, 773-42A

M. S. Hay, 773-42A

E. W. Holtzscheiter, 773-A

C. M. Jantzen, 773-A

D. P. Lambert, 704-1T

L. F. Landon, 704-1T

S. L. Marra, 704-T

D. Moore-Shedrow, 773-A

L. M. Papouchado, 773-A

D. K. Peeler, 773-43A

R. C. Tuckfield, 773-42A

\section{DWPF}

R. S. Beck, 704-28S

M. N. Brosee, 704-S

R. E. Edwards, Jr., 704-25S

H. H. Elder, 704-S

W. D. Kerley, 704-S

J. E. Occhipinti, 704-27S

J. F. Ortaldo, 704-S

J. W. Ray, 704-35S 